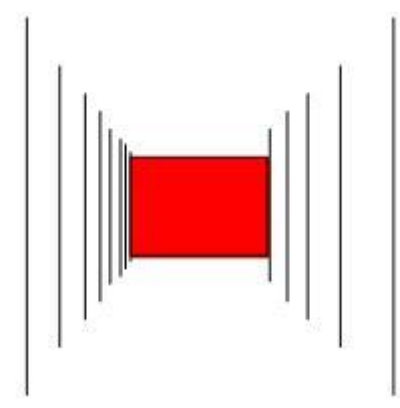
Centre for
Building
Performance
Research

\title{
A Natural Ventilation Calculator.
}

An investigation of active and passive ventilation measures for mitigating poor building performance in early design.

\author{
Jack Steele \\ Nilesh Bakshi \\ Michael Donn
}

Research and publication by the Centre for Building Performance Research, Victoria University of Wellington.

In partnership with:

Studio of Pacific Architecture.

February 2019 
Edition information

ISBN 978-0-475-12427-2

Authors: Jack Steele, Nilesh Bakshi, Michael Donn

Research Assistants: Jack Steele.

Partnering Researchers: The Research Group at Studio of Pacific Architecture

Report title. A Natural Ventilation Calculator: An investigation of active and passive ventilation measures for mitigating poor building performance in early design.

Centre for Building Performance Research,

Victoria University of Wellington,

P.O. Box 600, Wellington, New Zealand.

Phone + 6444636200 Facsimile + 6444636204

The Document Register is provided at the rear. 


\section{Preface}

This report presents the findings of the joint research project 'A Natural Ventilation Calculator: An investigation of active and passive ventilation measures for mitigating poor building performance in early design'. The project was in response to the notion that low indoor air quality is found in residential housing where air tight buildings are being built and occupants are not opening windows. The current study aims to identify successful methods of 1 ) calculating ventilation rates using natural ventilation formulae, and 2) displaying the process along with inputs required for a excel based calculator.

\section{Acknowledgments}

This work was funded by the joint investment of Studio of Pacific Architecture and the Victoria University of Wellington through the Victoria Summer Research Scholarship Programme.

This work is made possible by the valued efforts of the partnering researchers from the research group at Studio of Pacific Architecture.

\section{Notes}

This report is intended to aid designers in the delivery of more accurate, natural or mechanical ventilation systems in residential buildings. 


\section{Abstract}

Current design trends are making residential housing increasingly air tight. Quaglia and McNeil (2011), found that a modern house in New Zealand has an estimated infiltration rate of around 0.25 ach under standard pressure, whereas, international guidelines recommend a rate of between 0.35 ach to 0.5 ach. Designing ventilation sustainably, or to it well, is a balancing act, on one hand occupants want and require fresh air while on the other, don't want increased air conditioning costs.

This paper looks at the different types of ventilation, natural and mechanical, and the strategies that allow them to work, while also compiling information into an excel based ventilation calculator for practicing architects. The calculator acts as a workflow by assisting an architects when designing ventilation. Calculations are run to check the design against code requirements and then suggests ventilation options to meet said requirements.

This paper first identifies, ventilation strategies that can be designed into new residential housing including positive, negative, and balanced pressure systems. The effectiveness and calculations required to investigate each strategy is determined. Secondly, the differences that pressure variation can cause on the ventilation rate is determined and related to good design practices. 


\section{Table of Contents}

PREFACE

ACKNOWLEDGMENTS





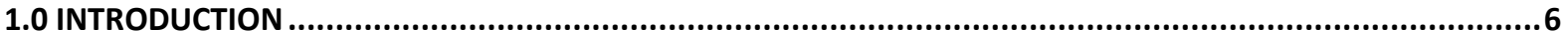

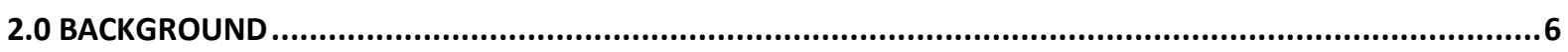

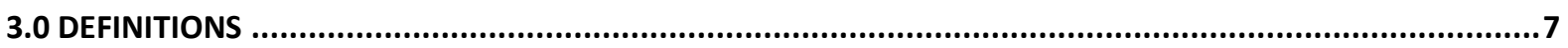

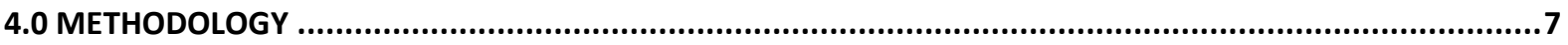

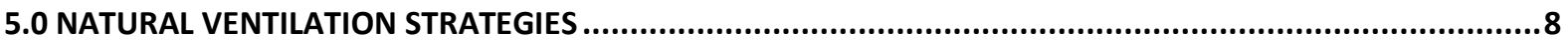

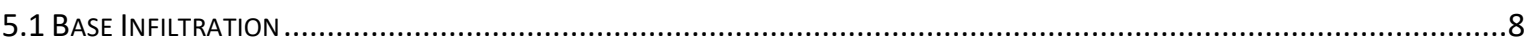

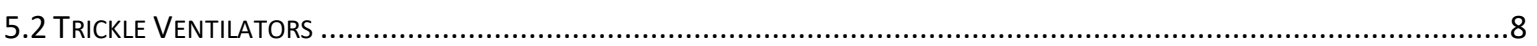

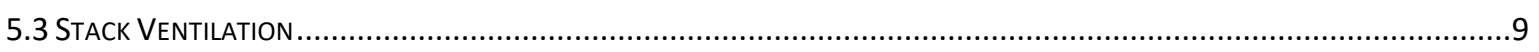

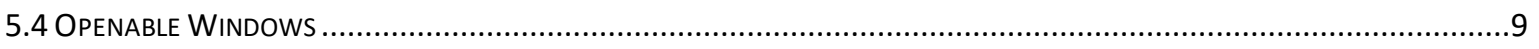

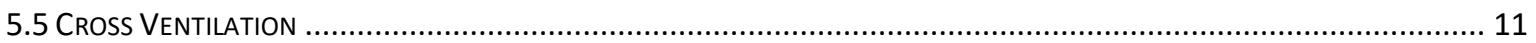

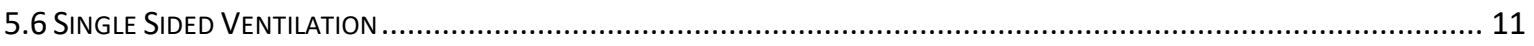

6.0 MECHANICAL VENTILATION STRATEGIES ........................................................................................14

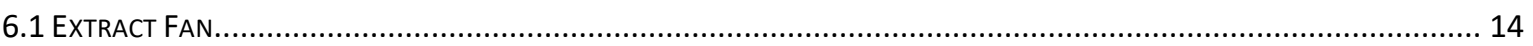

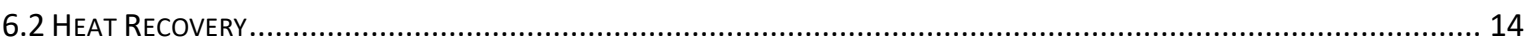

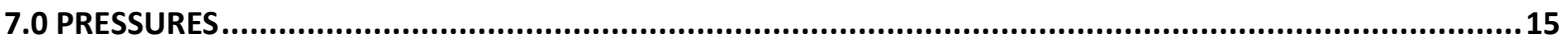

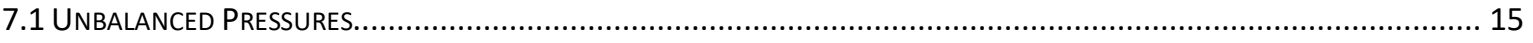

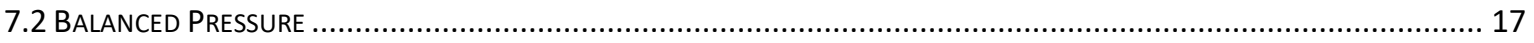

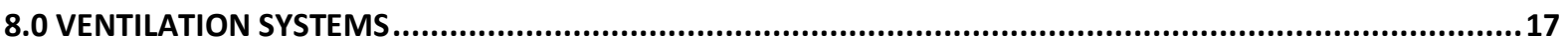

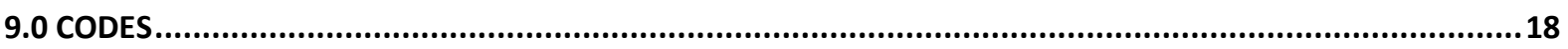

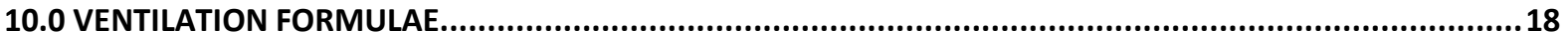

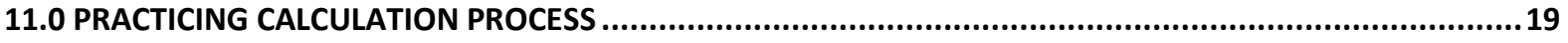

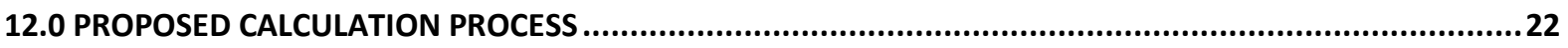

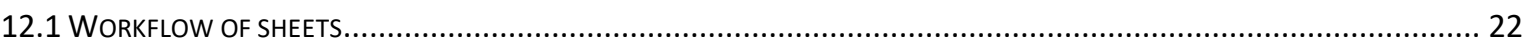

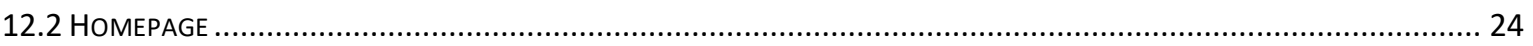

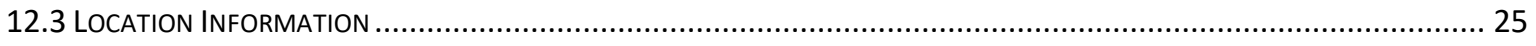

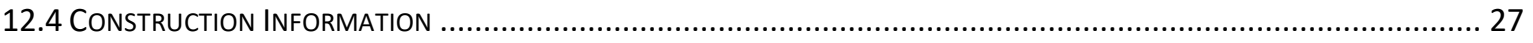

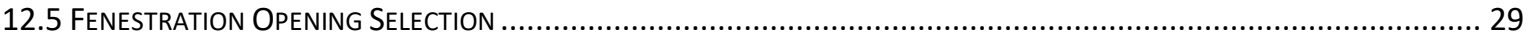

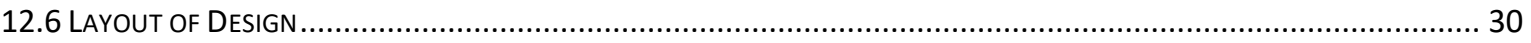

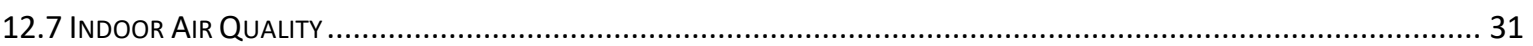

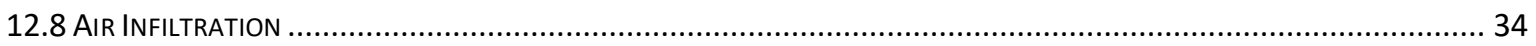

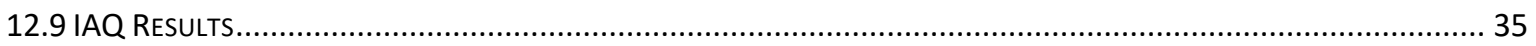

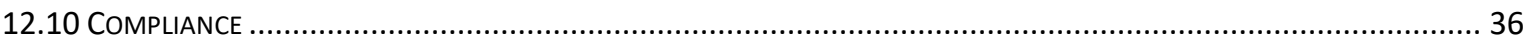

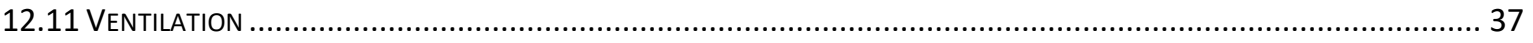

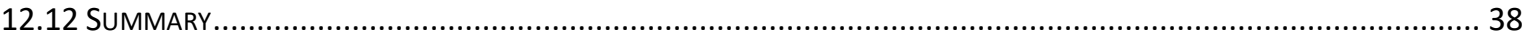

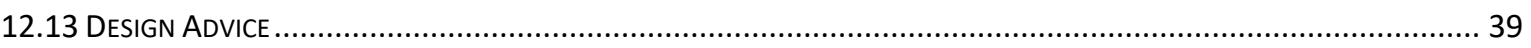

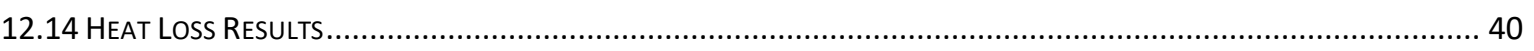

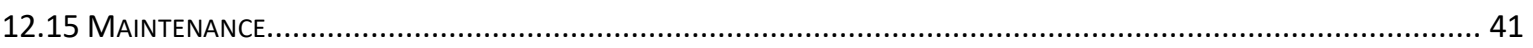

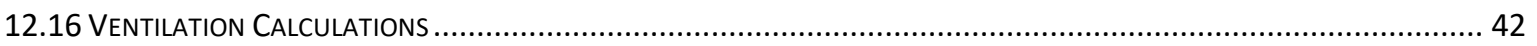

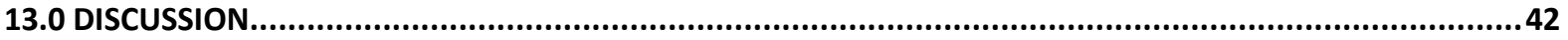




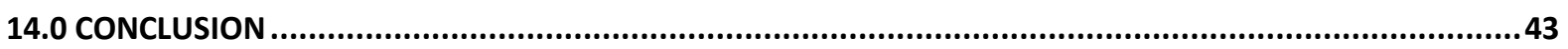

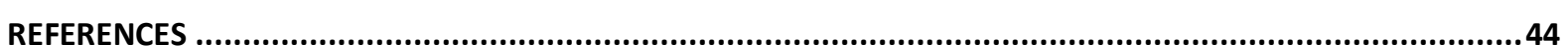

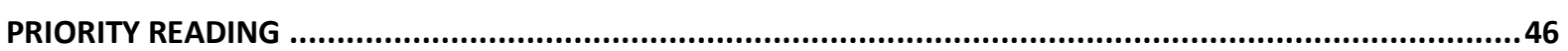

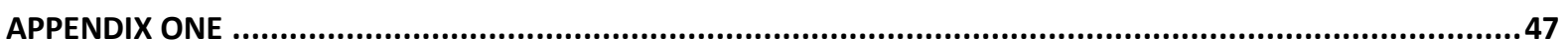




\subsection{Introduction}

This research paper investigates the development and application of a ventilation calculator used for mitigating poor building performance. The philosophy behind creating a tool to determine what ventilation methods would be best, comes from occupants not knowing how to operate their houses to produce effective and healthy environments. This involves considering existing calculation methods, and a range of ventilation techniques that are currently in-use to produce impactful results.

The work carried out, comprehensively defines and evaluates the implications of existing passive and active ventilation strategies. Passive ventilation is a natural ventilation system, it relies on natural forces such as wind or the stack effect to circulate air throughout a space. The alternative is active ventilation, this is provided through mechanical means such as extractor fans or balanced pressure heat recovery (BPHR).

A range of passive and active ventilation strategies are used to inform a spreadsheet calculator created out of the amalgamation of established calculation methods by Michael Donn and Nilesh Bakshi. This calculator although within Microsoft Excel, displays the meaningful information and guides the user through a workflow that is not overwhelming or complicated. Each section of the calculator has an individual dashboard for ease of use, while the calculation process and formula are concealed in the background.

\subsection{Background}

The homes in New Zealand used to be built with sufficient ventilation through natural air leakage paths (BRANZ, 2018). The current trend is to build more air tight homes so that internal environments can be controlled easily. On the extreme end of air tightness, the Passive House Institute of New Zealand requires an air change rate of 0.6 at 50 pascals, which is equivalent to 0.03 ach at standard pressures just through infiltration. Houses that follow this path must be designed well so that contaminants don't build up indoors making spaces uncomfortable to live within. This is normally achieved through the use of mechanical systems. 


\subsection{Definitions}

\begin{tabular}{|c|c|}
\hline Word/Phrase & Definition Within This Paper \\
\hline $\begin{array}{l}\text { Single Sided } \\
\text { Ventilation }\end{array}$ & Ventilation through only one external opening \\
\hline $\begin{array}{l}\text { Cross } \\
\text { Ventilation }\end{array}$ & Ventilation through two opposite or perpendicular external openings \\
\hline $\begin{array}{l}\text { Natural } \\
\text { Ventilation }\end{array}$ & $\begin{array}{l}\text { Natural ventilation is the process of bringing air in or removing stale air from } \\
\text { outdoors through means that don't require any mechanical systems to be } \\
\text { running, e.g. opening windows }\end{array}$ \\
\hline $\begin{array}{l}\text { Mechanical } \\
\text { Ventilation }\end{array}$ & $\begin{array}{l}\text { Mechanical ventilation is the process of bringing air in or removing stale air } \\
\text { from outdoors or circulating air via a fan or other system that requires } \\
\text { electrical work }\end{array}$ \\
\hline $\begin{array}{l}\text { Passive } \\
\text { Ventilation }\end{array}$ & $\begin{array}{l}\text { Passive ventilation is the process of bringing air in or removing stale air } \\
\text { through the means of no work being done and is usually a constant process }\end{array}$ \\
\hline Infiltration & $\begin{array}{l}\text { Infiltration is a sort of passive ventilation that occurs through the building } \\
\text { envelope, and is a biproduct of construction leaving small gaps }\end{array}$ \\
\hline Ach & Air changes per hour unpressurised \\
\hline Ach@50pa & Air changes per hour at 50pa, testing with a blower door test \\
\hline Low Activity & $\begin{array}{l}\text { The level for at which occupants are sitting most of the time and not } \\
\text { performing any strenuous activities }\end{array}$ \\
\hline $\begin{array}{l}\text { Average } \\
\text { Activity }\end{array}$ & $\begin{array}{l}\text { The level for at which occupants are walking around and completing } \\
\text { everyday activities }\end{array}$ \\
\hline $\begin{array}{l}\text { Medium } \\
\text { Activity }\end{array}$ & $\begin{array}{l}\text { The level for at which occupants are moving more than average while } \\
\text { performing household duties }\end{array}$ \\
\hline
\end{tabular}

\subsection{Methodology}




\subsection{Natural Ventilation Strategies}

Natural ventilation is the process of supplying and or removing air from an internal space without the use of mechanical systems usually through wind or thermodynamic principles. A range of natural ventilation strategies are reported in the section below, along with their effectiveness and how they work. In addition, formulas are given for calculating ventilation rates using certain strategies.

\subsection{Base Infiltration}

The older a building the more leaky it is in terms of air movement, this loss and gain of air is called infiltration. Leakage is predominantly through the external façade, where windows, doors, or any penetrations have not been completely sealed. This is not at fault of the builder, but of the material choices and joinery. It is possible to achieve almost no infiltration if specific techniques are used. A natural base infiltration can be seen as a good thing and as a bad thing. For passive ventilation it provides a steady and constant flow of air no matter if the windows are open or closed. If this base level is high enough it can remove some low producing pollutants from a space. Infiltration has also been seen as bad as it is uncontrollable and can make the function of a mechanical ventilation system work harder. Modern houses are becoming increasingly air tight due to better construction methods and material choices. Quaglia and McNeil (2011) report that a modern house has an estimated infiltration rate of around 0.25 ach. While, international guidelines recommend a ventilation rate of between 0.35 ach and 0.5 ach to effectively remove contaminants, but not high enough to effect energy efficiency.

Research from Bassett (2001) shows base infiltration rates can be identified for different age and construction type buildings.

Table 1: (Bassett, 2001)

\begin{tabular}{|c|c|}
\hline Type Description & Base level Infiltration Rate (ach) \\
\hline Airtight & 0.3 \\
\hline Average & 0.5 \\
\hline Leaky & 0.7 \\
\hline Draughty & 0.9 \\
\hline
\end{tabular}

These base values are then corrected with specific building features that would alter the infiltration. The third step in the process is to adjust for regional location, through correcting with the regional factors a more approximate value is gained. A final step adjusts for the local wind exposure of the site, this is another multiplication factor. These categories are exposed, semi-exposed, semi-sheltered, and sheltered.

\subsection{Trickle Ventilators}

Trickle vents are very small openings normally found around the frame of windows, but can be installed through any part of a buildings envelope. Although they are typically long and narrow they come in a variety of shapes but must be $2000 \mathrm{~mm}^{2}$ or larger. A total equivalent 
ventilation area for different levels of occupants is found in section $\mathrm{G} 4$ of the New Zealand Building Code, this sets out the required openings for different spaces (MBIE, 2017). A factor around these vents is that they can be opened or closed at the users discretion, this also provides the possibility of being left open when occupants are away, but also allows for the user to never open them.

In the United Kingdom, Sharpe et al. (2015) conducted a survey of occupants over 200 houses with trickle ventilators. The survey identified that there is little interaction with them, $63 \%$ of respondents reported that vents in bedrooms and living rooms remain closed constantly. While, in only $13 \%$ of living rooms and $9 \%$ of bedrooms are adjusted weekly. The outlying reason for this finding is shown through the response that they "don't feel the need to open vents". Although, it is evident through $\mathrm{CO}_{2}$ calculations that spaces with trickle vents open have lower levels than spaces with them closed. However, these values are still ineffective at meeting desired ventilation rates, as $42 \%$ of cases had rates lower than an equivalent air change rate of 0.5 .

\subsection{Stack Ventilation}

An effective form of natural ventilation is to use a passive stack strategy. This uses the idea of buoyancy, or that warm air is lighter and therefore rises. By adapting this effect through having low and high placed windows or a "stack", essentially a chimney, designs can produce differing air pressures causing air movement and natural ventilation. For smaller residential buildings stack ventilation is a realistic strategy, but when a large building is situated in a dense urban environment sufficient amounts of wind to generate suction can be harder to obtain.

In a study by Priyadarsini et al. (2004) of high rise buildings in Singapore, it's found that ventilation systems solely using buoyancy as the passive stack effect could not generate the pressure differentials to initiate air movement. An improvement to the ventilation rates came from installing a DC fan to promote air movement within the tall stack.

Stack or buoyancy pressure can be calculated using the formula provided in the report by Atkinson J et al. (2009), shown in the Appendix. This calculation uses the density and temperature of indoor and outdoor air, in addition to, the difference in height between the two openings. Another formula, below in Figure 1, is used to find the ventilation rate of a space using similar values and the smallest opening area.

$$
A C H=\frac{0.15 * \text { Opening Area } * 3600 * \sqrt{\left(T_{\text {in }}-T_{\text {out }} * H\right)}}{V}
$$

\subsection{Openable Windows}

The most common way of achieving a natural ventilated space is to have openable windows. Although there are numerous styles and designs of windows that can affect how much air flow is generated, the more important factor is their location. Ventilation rates for a space change extensively whether there is single sided ventilation or cross ventilation. The most effective placement is to have windows on opposite sides of a room so that air can pass directly through without any obstructions. A similar method but less effective is to 
have windows on adjacent walls. While, the least productive solution is to have windows on the same wall as each other (BRANZ, 2017).

The styles of windows listed below, show the effectiveness of air flow through that window type. This factor must also be considered as the effects on ventilation rates can be substantially different with different styles. REFERENCE

Table 2: Window Styles

\begin{tabular}{|c|c|c|}
\hline Window Style & Effective Percentage \\
\hline Casement & & $90 \%$ \\
\hline Single/Double hung & & \\
\hline Slider & & \\
\hline Hopper & & \\
\hline Awning & & \\
\hline
\end{tabular}

When wind strikes a building pressures are applied to it. For cross ventilation the windward side has positive pressure forces placed on it, which forces air into a room. While, on the leeward side a negative suction pressure is exerted, this pulls air out of the building. For single sided ventilation only one of these actions happens leading to less air movement. In a perfectly sealed example of a single sided room, pressures would just fluctuate leading to very small amounts of ventilation. As over time seals weaken and penetrations widen air change increases leading to arguably better performing houses. 


\subsection{Cross Ventilation}

Ventilation rates from cross ventilation can be calculated using another formula from Atkinson J et al. (2009) shown below in formula 2. This uses the local windspeed, opening area, and the room volume in addition to other set values. This assumes that there is no obstacles blocking the path of air flow that would slow the thoroughfare.

$$
\text { ACH }=\frac{0.65 * \text { Wind Speed }(\mathrm{m} / \mathrm{s}) * \text { Smallest Opening Area }\left(\mathrm{m}^{2}\right) * 3600 \mathrm{~s} / \mathrm{h}}{\text { Room Volume }\left(\mathrm{m}^{3}\right)}
$$

The 0.65 shown in this equation is the pressure difference $(\Delta C p)$ between the two sides of a space. This value changes dependent on where the windows are located. An assumption is that the wind is always a northerly is made here so that pressure differences can be calculated. Using Table 3 below $\mathrm{Cp}$ can be calculated, minus the number below the directions the windows are on from each other.

Table 3: Pressure Coefficient Calculation

\begin{tabular}{|c|c|c|c|}
\hline North & East & South & West \\
\hline 0.4 & -0.4 & -0.25 & -0.4 \\
\hline
\end{tabular}

\subsection{Single Sided Ventilation}

There are three base equations proposed by the British Standard Method to determine single sided ventilation rates due to wind alone, temperature difference, and temperature difference with two openings (Santamouris and Asimakopoulos, 1997). These equations ignore all internal partitions and assume two dimensional flow.

The first equation for ventilation due to wind only is below in equation 3 . It calculates the ventilation rate, where $A$ is the opening surface area and $V$ is the wind velocity.

$$
Q=0.025 A V
$$

The equation for ventilation due to temperature differences with one opening is shown in equation 4 below. This uses additional factors where $\Delta T$ is the change in temperature from outside to inside, and $\bar{T}$ is the average temperature difference. $C_{d}$ is also used this is the discharge coefficient which can be assumed to be 0.6 .

$$
Q=C_{d} \frac{A}{3} \sqrt{\frac{\Delta T g H_{1}}{\bar{T}}}
$$

For the temperature difference between two openings the area of each opening and the distance apart needs to be known. $A_{1}$ is the top window, $A_{2}$ the bottom, and $\mathrm{H}_{2}$ the distance. The equation 5 shown below needs to be calculated first, so that $\varepsilon$ can be translated into equation 6.

$$
\varepsilon=\frac{A_{1}}{A_{2}}
$$




$$
Q=C_{d}\left(A_{1}+A_{2}\right)\left[\frac{\varepsilon \sqrt{2}}{(1+\varepsilon)\left(1+\varepsilon^{2}\right)^{1 / 2}}\right]\left(\frac{\Delta T g H_{2}}{\bar{T}}\right)^{1 / 2}
$$

These equations are a very basic calculation for the ventilation rates caused but different effects. They lack a lot of context and can only be used for basic design calculations. Another down side to these equations is that there is no proposed equation within the set to combine the effects of wind and temperature difference. Although in single sided ventilation stack flow is a larger contribution to the ventilation rate, meaning that the wind is not so important (Santamouris and Asimakopoulos, 1997).

In the CIBSE (1997) guide to natural ventilation, a set of formula from Warren and Parkins (1984) are used to calculate the combined effects of wind and stack effects. This is the expansion on the previous work which makes the equations more useful. Wind only ventilation, $Q_{w}$ can be calculated using formula 7 below. Where $A$ is the open area, and $U$ is the wind speed at the building height. Stack driven flow, $Q_{s}$ is given by formula 8 . Where the acceleration due to gravity is $\mathrm{g}, \mathrm{h}$ is the height of the opening, $\Delta \mathrm{T}$ is the difference in temperature between the outside and inside air, and $T_{a v}$ is the average temperature of the inside and outside air. The wind and stack driven flows can then be combined using the third equation below, equation 9, to get $Q_{\text {тот }}$ which is the overall amount of ventilation for single sided ventilation. This is the first set to combine these effects.

$$
\begin{aligned}
& Q_{W}=0.05 A U \\
& Q_{S}=0.2 A\left(\frac{g h \Delta T}{T_{a v}}\right)^{\frac{1}{2}} \\
& Q_{T O T}=\left(Q_{W}^{2}+Q_{S}^{2}\right)^{\frac{1}{2}}
\end{aligned}
$$

Warrens earlier work (Warren, 1977) contains a set with two similar formulas except for one slight difference in the second equation, equation 11.

$$
\begin{aligned}
& Q_{\text {stack }}=\frac{1}{3} A_{\text {eff }} C_{d} \sqrt{\frac{\Delta T H g}{T_{\text {ave }}}} \\
& Q_{w}=0.025 A_{\text {eff }} U_{w}
\end{aligned}
$$

$\mathrm{Q}_{\text {stack }}$ is the buoyancy driven ventilation rate, this is calculated using $A_{\text {eff }}$ which is the effective opening area, $\Delta T$ is the difference in temperature, $\mathrm{H}$ is the height, $\mathrm{g}$ is the acceleration due to gravity, $T_{\text {ave }}$ is the average temperature of inside and outside, and a displacement coefficient, $C_{d}$ of 0.6 . This is the same as formula 3 above. In equation 11 where $A_{\text {eff }}$ is still the effective opening area and $U_{w}$ is the wind speed at the building height. There is a difference with the initial factor that was used as 0.05 in equation 7.

An advancement by De (Gids and Phaff, 1982) incorporated additional empirical constants, $C_{1}, C_{2}$, and $C_{3}$ these are used to represent the wind effect, buoyancy constant, and turbulence constant, respectively. Thirty-three experiments were completed by Phaff and 
De Gids and the best overall fit produced the constant values where $C_{1}=0.001 C_{2}=0.0035$ and $C_{3}=0.01$.

$$
U_{e f f}=\sqrt{C_{1} U_{w}^{2}+C_{2} H \Delta T+C_{3}}
$$

The $U_{\text {eff }}$ from equation 12 above is used to calculate $Q$, the ventilation rate in equation 13 below. A coefficient of 0.5 is used in this case to represent the assumption that each incoming and outgoing flow consists of half of the opening area. The value $C_{d}$ is included in $U_{\text {eff }}$, this decision makes the accuracy of the calculation dependent on window type since it is not possible to change the characteristics of the window in the expression simply by changing the $C_{d}$ value.

$$
Q=0.5 A U_{e f f}
$$

Based on Phaff and De Gids work, Larsen and Heiselberg, 2008 made a more complex correlation shown below in equation 14 , is able to be made. This now considers different wind directions, where $f(\theta)$ is the function of wind incident angle determined experimentally and $\Delta C_{p}$ is the largest measured deviation of the $C_{p}$ at the opening.

$$
U_{e f f}=\sqrt{C_{1} f(\varnothing)^{2}\left|C_{p}\right| U_{r e f}^{2}+C_{2} H \Delta T+C_{3} \frac{\Delta C_{p} \Delta T}{U_{r e f}^{2}}}
$$

Variations on the constant values $C_{1}, C_{2}$, and $C_{3}$ by De Gids and Phaff are proposed to relate to the incidence angle of the wind. These values are shown below.

Table 4: Constant values for different wind directions, (Larsen and Heiselberg, 2008)

\begin{tabular}{|l|l|c|c|c|c|}
\hline Direction & Incidence angle, $\emptyset$ & C1 & C2 & C3 & $\begin{array}{c}\text { Average } \\
\text { deviation }\end{array}$ \\
\hline Windward & $\emptyset=0^{\circ}-75^{\circ}, \emptyset=285^{\circ}-360^{\circ}$ & 0.0015 & 0.0009 & -0.0005 & $28 \%$ \\
\hline Leeward & $\varnothing=105^{\circ}-255^{\circ}$ & 0.0050 & 0.0009 & 0.0160 & $19 \%$ \\
\hline Parallel flow & $\varnothing=90^{\circ}, \emptyset=270^{\circ}$ & 0.0010 & 0.0005 & 0.0111 & $18 \%$ \\
\hline
\end{tabular}

Most recently Wang and Chen (2012) developed a method to additionally predict the effects of fluctuating ventilation due to a pulsating flow. This was done as it is assumed that there is not an even pressure form the wind over a window. Wang and Chen's equation shown below is also the most complicated requiring integration to solve for the new wind effects.

$$
\sigma_{Q_{p}}^{2}=\left(\frac{C_{d} l \sqrt{C_{p}} \int_{z_{0}}^{h} \sqrt{z^{2 / 7}-z_{0}^{2 / 7}} d z}{z_{r e f}^{1 / 7}}\right)^{2} \sigma_{v}^{2}
$$

This equation has not been considered in the ventilation calculator as applying integration within Microsoft Excel is not able to be done.

Wind around a building induces pressures, this pressure changes is influenced by surrounding obstructions and the local wind characteristics. The pressures differ with wind 
direction, causing positive and negative changes. The pressure coefficient or $C_{p}$ is a dimensionless value that accounts for changes in wind induced pressure. From Santamouris and Asimakopoulos (1997), information about a general pressure coefficient can be found. Table 5 below shows a selection of $C_{p}$ values for just a standard wall with an aspect ratio of $1: 1$.

Table 5: Different Pressure Values, Santamouris and Asimakopoulos (1997)

\begin{tabular}{|l|c|c|c|c|c|c|c|c|}
\hline Angle & $0^{\circ}$ & $45^{\circ}$ & $90^{\circ}$ & $135^{\circ}$ & $180^{\circ}$ & $225^{\circ}$ & $270^{\circ}$ & $315^{\circ}$ \\
\hline Exposed $\left(C_{p}\right)$ & 0.7 & 0.35 & -0.5 & -0.4 & -0.2 & -0.4 & -0.5 & 0.35 \\
\hline Semi-Exposed $\left(C_{p}\right)$ & 0.4 & 0.1 & -0.3 & -0.35 & -0.2 & -0.35 & -0.3 & 0.1 \\
\hline Sheltered $\left(C_{p}\right)$ & 0.2 & 0.05 & -0.25 & -0.3 & -0.25 & -0.3 & -0.25 & 0.05 \\
\hline
\end{tabular}

\subsection{Mechanical Ventilation Strategies}

Mechanical ventilation is the opposite process of natural ventilation. Air is moved through means of mechanical systems using fans. Below are strategies involving mechanical systems to ventilate houses.

\subsection{Extract Fan}

Air extract systems are primarily used in areas where excess amounts of moisture or contaminates are produced, these spaces tend to be kitchens, bathrooms, and toilets. The simplest form of extract system is to have a small mechanical extract fan in these locations. Extract fans create a negative air pressure inside a space, which sucks out the moisture or contaminates. For example, air from a hallway is sucked into the bathroom which is then expelled outside through the extract fan. As this system is active, energy is consumed for the work to be completed. This means that high powered fans should only be used when contaminates are produced and remain off the rest of the time.

New Zealand standard, NZS 4303:1990 Ventilation for acceptable indoor air quality, states minimum extract flow rates for kitchens and bathrooms. These are spaces within a house that require a high level of ventilation and typically have an extract fan. Although, in a BRANZ study report it was found that only half of bathrooms and half of kitchens had mechanical ventilation to outside (White and Jones, 2017). The two options, intermittent or continuous is up to the designer as there are benefits for both options. Intermittent ventilation can help get vast amounts of moisture and smells from a kitchen when an occupant is cooking, while it does nothing during the rest of the time. Whereas, continuous ventilation almost has the opposite problem, it deals with providing fresh air all day but cannot provide a high enough ventilation rate when cooking occurs.

\subsection{Heat Recovery}

Heat exchangers are simple in theory, they transfer energy (heat) from one source to another. They do this by passing warm indoor air past cooler fresh air, with a thin conductive material separating them. The advantage of this is that fresh air can be brought into a space while being pre heated to a higher temperature than outdoors. Thereby, saving 
energy by having to add a lowered amount of energy to bring the air up to a set point. The incoming air is heated by the exhaust air which is already at the aforementioned setpoint, although this is not performed at an $100 \%$ efficiency.

A balanced pressure heat exchanger (BPHE) is a mechanical ventilation system that uses fans to bring air into and out of a space. Although, what is described above is the optimal performance, there are many factors such as the base infiltration rate, or whether windows are open which can effect performance.

Tabled below are a range of effective efficiencies for general BPHE systems. These have been given from computer models, experimental tests, and guidelines. The lowest and most conservative estimation from Choi et al. (2018) is based on long term field measurements and is stated as sensible values. These are a lot different from what is required by Passivhaus. To achieve the Passivhaus requirements, the efficiency of a heat recovery systems must be over $75 \%$, it is also suggested that there are units with efficiencies of $90 \%$ (Cotterell and Dadeby, 2012). The three other sources for efficiencies are within this $75 \%+$ range.

Table 6: BPHE Efficiencies

\begin{tabular}{|c|c|}
\hline Efficiencies & Source \\
\hline$<75 \%$ & Cotterell and Dadeby (2012) \\
\hline$\sim 75 \%$ & AKBARI and OMAN (2013) \\
\hline$\sim 30 \%$ to $\sim 65 \%$ & Choi et al. (2018) \\
\hline$\sim 80 \%$ & Ginestet et al. (2014) \\
\hline$\sim 56 \%$ to $\sim 75 \%$ & Jokisalo et al. (2016) \\
\hline
\end{tabular}

\subsection{Pressures}

The ventilation strategies in Section 5.0 Natural Ventilation Strategies and 6.0 Mechanical Ventilation Strategies create and or are caused by different types of pressurised spaces. A space can have unbalanced pressure (positively pressured and negatively pressured) or have a balanced pressure, which has previously been mentioned in terms of a balanced pressure heat exchanger. Although there are different effects for each state of pressure they all promote the movement of air which if moved correctly can ventilate.

\subsection{Unbalanced Pressures}

Positive and negative unbalanced pressures essentially do the same thing, move air, but in opposite directions. Both of these are used extensively in hospitals to provide patients with either direct clean air or to stop infectious illness from spreading through the air. In these situations positive pressure is used when someone in a room needs clean air so wounds don't get infected, in this case the air then passes out of the room and into the main supply. The other situation, where negative pressure is used, is when air cannot be recycled in the main supply as it could risk disease spreading. The "used" air is filtered and exhausted from the building. However, in residential construction it is more common to only have negative 
pressure systems in a household, and a duel system would not be used as the main means of ventilation for the whole house.

Positive pressure gets its name from bringing air into a space, in turn, increasing the internal air pressure compared to outside. As there is an internal positive pressure, everything tries to balance, forcing air to escape out through gaps in the facade, windows, or passive grills. To achieve positive pressure there needs to be air moving into a space, this can be driven naturally by wind or mechanically by fans.

In the images below air flow is described by arrows in a positive pressure system. The diagram on the left shows a simple fan and outlet, the air would flow through the main section of the house and escape through windows, the desired vent, or gaps in the façade. Lower ventilation rates would be seen in the rooms without venting, as the pressure finds the least resistive path to neutralise. Whereas, in the image on the right a mechanical system can be seen circulating fresh air directly into each room. This method lets the exact rate be determined and adjusted individually. Although both systems have slight differences, the ventilation rates that can be achieved are similar.
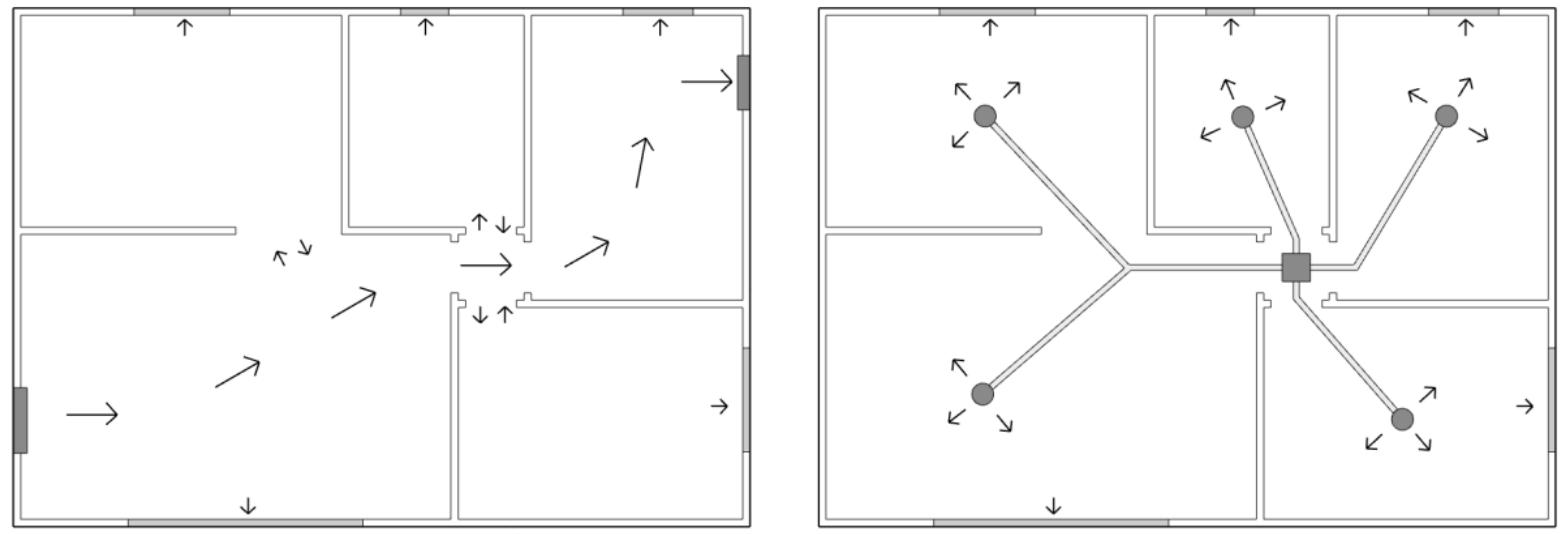

Figure 1: Positive pressure path through a house

Positive pressure works best when there is an outlet for the air to go, if this is not done ventilation rates can max out at the houses base infiltration rate. By using positive pressure the location of incoming air can be controlled directly in addition to outgoing if passive grills are used.

Negative pressure is named so because internal spaces have a lower air pressure than the outside. This is achieved by extracting air from rooms or the house, air from outside infiltrates in through gaps, windows or passive grills, essentially the opposite of positive pressure. 

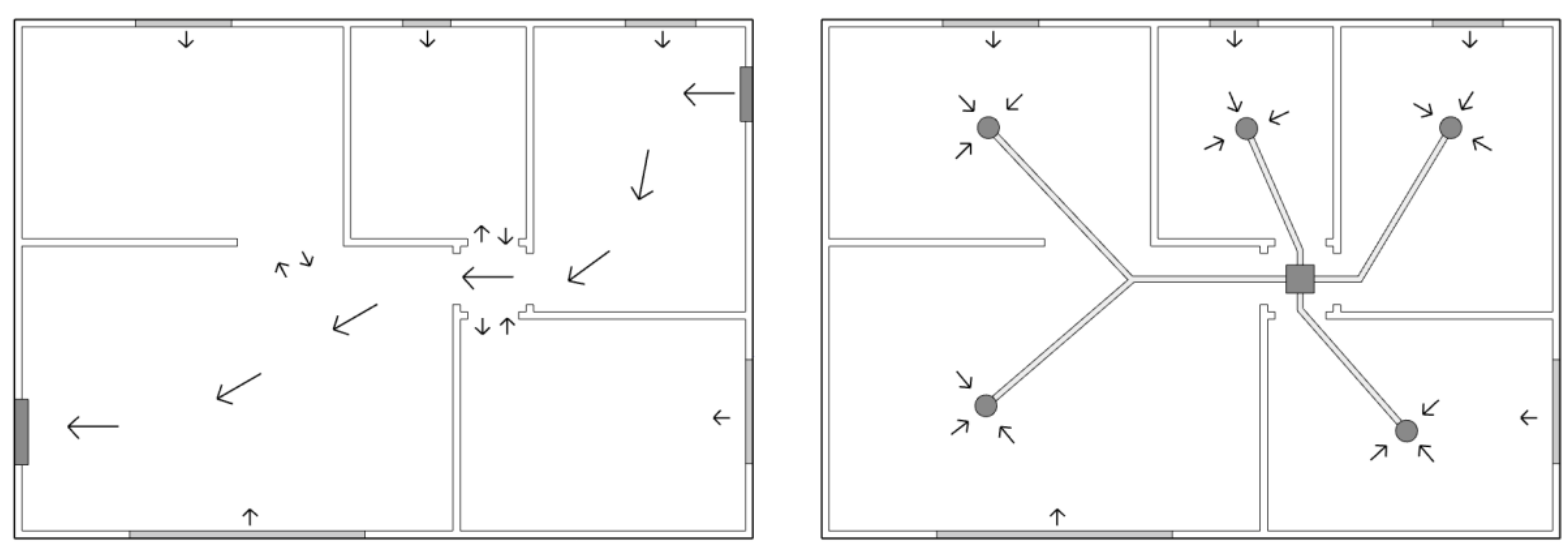

Figure 2: Negative pressure path through a house

\subsection{Balanced Pressure}

The term balanced pressure is used and the internal space is not be pressurised by having one fan pumping air in, or being depressurised by having one fan pumping out. A balanced pressure system has means of ventilating at the intake and outtake points, through having fans on either side of a house. This generates localised positive and negative pressures by the fans and creates air flow. An advantage to having a balanced pressure system is that flow rates in and out can be directly controlled, leaving the system to preform optimally and adjust when there are influxes of pollutants. As mentioned earlier in 6.2 Heat Recovery, a BPHE uses this principle to optimally extract heat from outgoing air.

\subsection{Ventilation Systems}

Different ventilation systems provide differing amounts of air per second, a range of these have been compiled from manufactures so that bands of effectiveness can be seen.

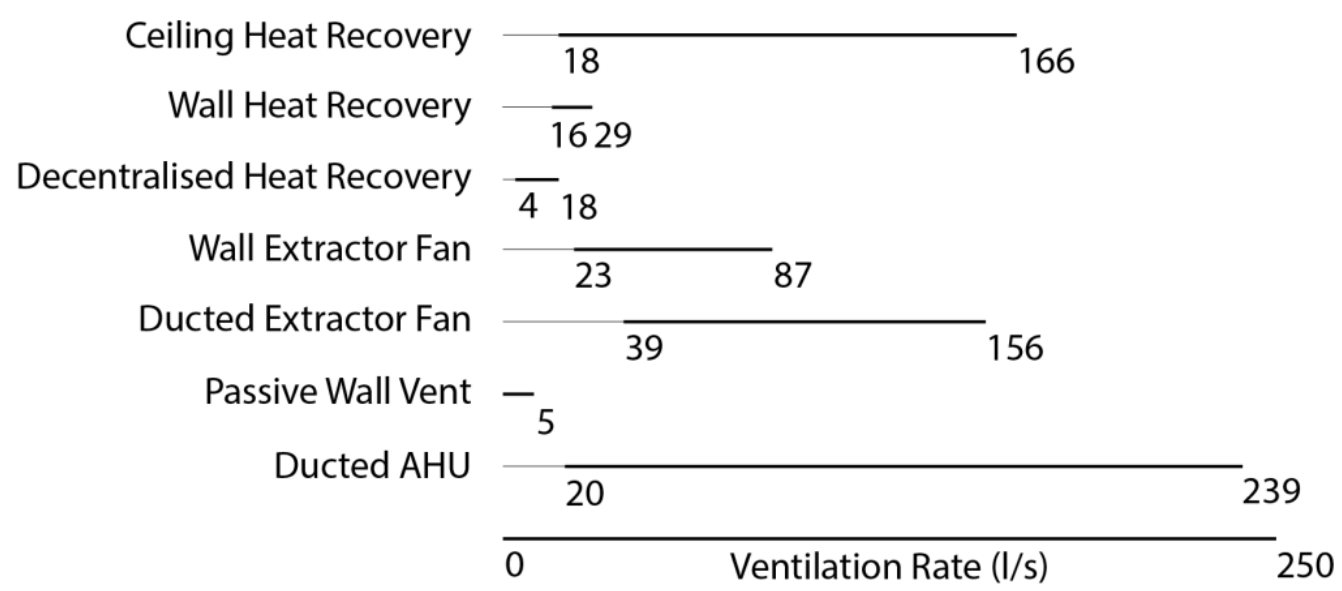

Figure 3: User free Ventilation systems

The lowest providable ventilation is from the only non-mechanical system, passive wall vents, or trickle vents. This strategy is suggested most often when analysing single rooms as they tend to only need a small amount of additional ventilation. For a bathroom or a kitchen where rates are higher, some of the other systems come into effectiveness. When looking at 
the house as a whole the larger ventilation rates become more useful as a single system can provide the necessary rates. A table of all the current systems that are in the sheet can be seen in Appendix One.

\subsection{Codes}

Required ventilation rates can be found in NZS4303:1990, AS1668.2, ASRAE 62.2, and British Building Regulations Part F. Although, NZS4303 is the only standard that can be used to prove compliance using ventilation rates in New Zealand. Below in Table 7, these ventilation rates are shown. In the standard less space types are given, they have been expanded on here to represent space types found in a house.

Table 7: Ventilation Requirements

\begin{tabular}{|c|c|c|}
\hline Space Type & Intermittent & Continuous \\
\hline Living Areas & - & 0.35 ach \\
\hline Kitchen & $50 \mathrm{l} / \mathrm{s}$ & $12 \mathrm{l} / \mathrm{s}$ \\
\hline Bathroom & $25 \mathrm{~s} / \mathrm{s}$ & $10 \mathrm{~s}$ \\
\hline Toilet & $25 \mathrm{~s} / \mathrm{s}$ & $10 \mathrm{~s} / \mathrm{s}$ \\
\hline Bedroom & - & $0.35 \mathrm{ach}$ \\
\hline Laundry & - & $25 \mathrm{l} / \mathrm{s}$ \\
\hline Study & - & $0.35 \mathrm{ach}$ \\
\hline Hallway & - & $1 \mathrm{~s}$ \\
\hline Garage & - & $1 \mathrm{~s} / \mathrm{s}$ \\
\hline Attic & - & $10 \mathrm{~s}$ \\
\hline Dining & - & $0.5 \mathrm{ach}$ \\
\hline
\end{tabular}

\subsection{Ventilation Formulae}

With all of the different formulae improving on each other for calculating single sided ventilation, only one can be used as the standard. Equations 3 and 4 begin simply by calculating wind and stack driven ventilation separately, while the later equations from Wang and Chen require integration. These equations span the range between being useful for design to analysis. The complexity increases due to trying to better represent reality, or to back up computational fluid dynamics calculations.

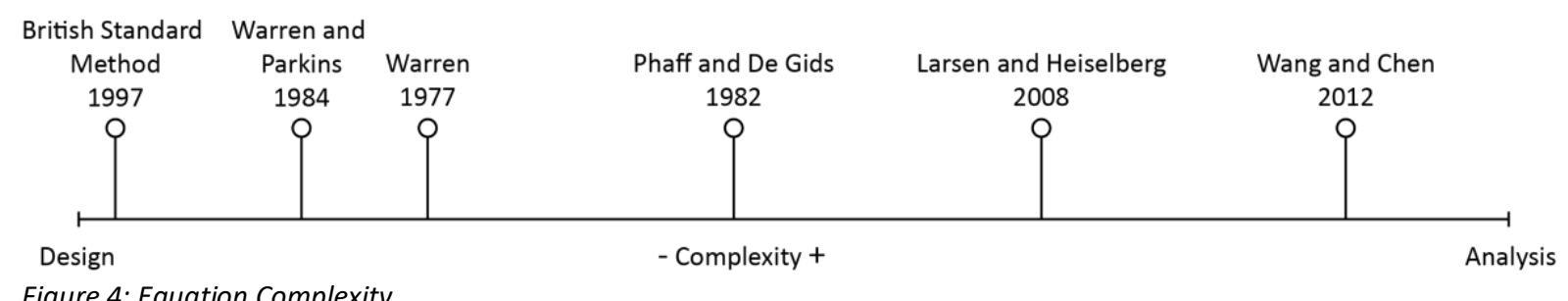

Figure 4: Equation Complexity 
The ventilation calculator being produced alongside this report is for architectural design therefore, the lower complexity calculations are more useful. Specific inputs for the complex equations are only obtainable through estimation or CFD, this data is not normally available at the start of a project.

While the first three equation sets the British Standard Method, Warren and Parkins, and Warren essentially look at only wind and stack effects. Therefore, they are not applicable to a wide enough range of situations to be used for architectural design. The fourth equation on the list, from Phaff and De Gids, includes additional constant factors making it more in line with the effects of wind from any direction. The Phaff and De Gids formula is used throughout the European standard EN 16798-7 as it gives reasonable average air flow values through openings. The most complex equation that can be used in excel from Larsen and Heiselberg gives different constant values depending on wind direction. As this tool is predominantly used for preliminary design and not assessment of existing builds, wind direction is likely unknown, therefore, irrelevant.

Below in Table 8, the ventilation rates of a $10 \mathrm{~m}^{2}, 24 \mathrm{~m}^{3}$ space are given for each corresponding formula. Every aspect about the calculator remains the save, only one variable is changed and that's the windows size.

Ventilation results range vastly over each calculation, up to eight times larger. The formula being used from Phaff and De Gids, is close to the average of the range. However the simplest on the formula which involves wind only calculations, using the British Standard Method is actually the closest to the average ventilation rate. Although, this doesn't not mean it is any more accurate or reflective of reality.

Table 8: Formula Results

\begin{tabular}{|c|c|c|c|c|c|c|}
\hline $\begin{array}{c}\text { Window } \\
\text { Size }(\mathrm{m})\end{array}$ & $\begin{array}{c}\text { BSM Wind } \\
\left(\mathrm{m}^{3} / \mathrm{s}\right)\end{array}$ & $\begin{array}{c}\text { BSM Temp } \\
\left(\mathrm{m}^{3} / \mathrm{s}\right)\end{array}$ & $\begin{array}{c}\text { Warren and } \\
\text { Parkins } \\
\left(\mathrm{m}^{3} / \mathrm{s}\right)\end{array}$ & $\begin{array}{c}\text { Warren } \\
\left(\mathrm{m}^{3} / \mathrm{s}\right)\end{array}$ & $\begin{array}{c}\text { Phaff and } \\
\text { De Gids } \\
\left(\mathrm{m}^{3} / \mathrm{s}\right)\end{array}$ & $\begin{array}{c}\text { Larsen and } \\
\text { Heiselberg } \\
\left(\mathrm{m}^{3} / \mathrm{s}\right)\end{array}$ \\
\hline $0.5 \times 2$ & 0.063 & 0.027 & 0.129 & 0.069 & 0.051 & 0.016 \\
\hline $1 \times 2$ & 0.126 & 0.076 & 0.264 & 0.147 & 0.110 & 0.039 \\
\hline $2 \times 2$ & 0.253 & 0.215 & 0.549 & 0.331 & 0.251 & 0.100 \\
\hline
\end{tabular}

\subsection{Practicing Calculation Process}

Below in Figure 5, the workflow used by practicing architects is shown. It is used to calculate ventilation rates, determine what fans or systems to use, and provide compliance documentation. Almost every step involves finding information from codes, plans, or product manuals, this makes the process of designing food ventilation harder and time 
consuming. The initial dividing factor in the process is whether the calculation is for compliance or not, this determines if a room by room calculation, or whole house calculation is used.

With different means of compliance for different spaces types, the architect is forced to manually determine what is best for each space and calculate the rates that would be achieved. This is a problem as, without actually knowing how the airflow works, all the architect can claim is that the ventilation rate is above or at what is required.

A limitation to this process, is that typological information is not considered. The local wind levels, as well as solar heat gains play a part in the internal environment. For these to be considered, a more advanced calculation method and process must be put forth that can account for varying wind levels and typology. 


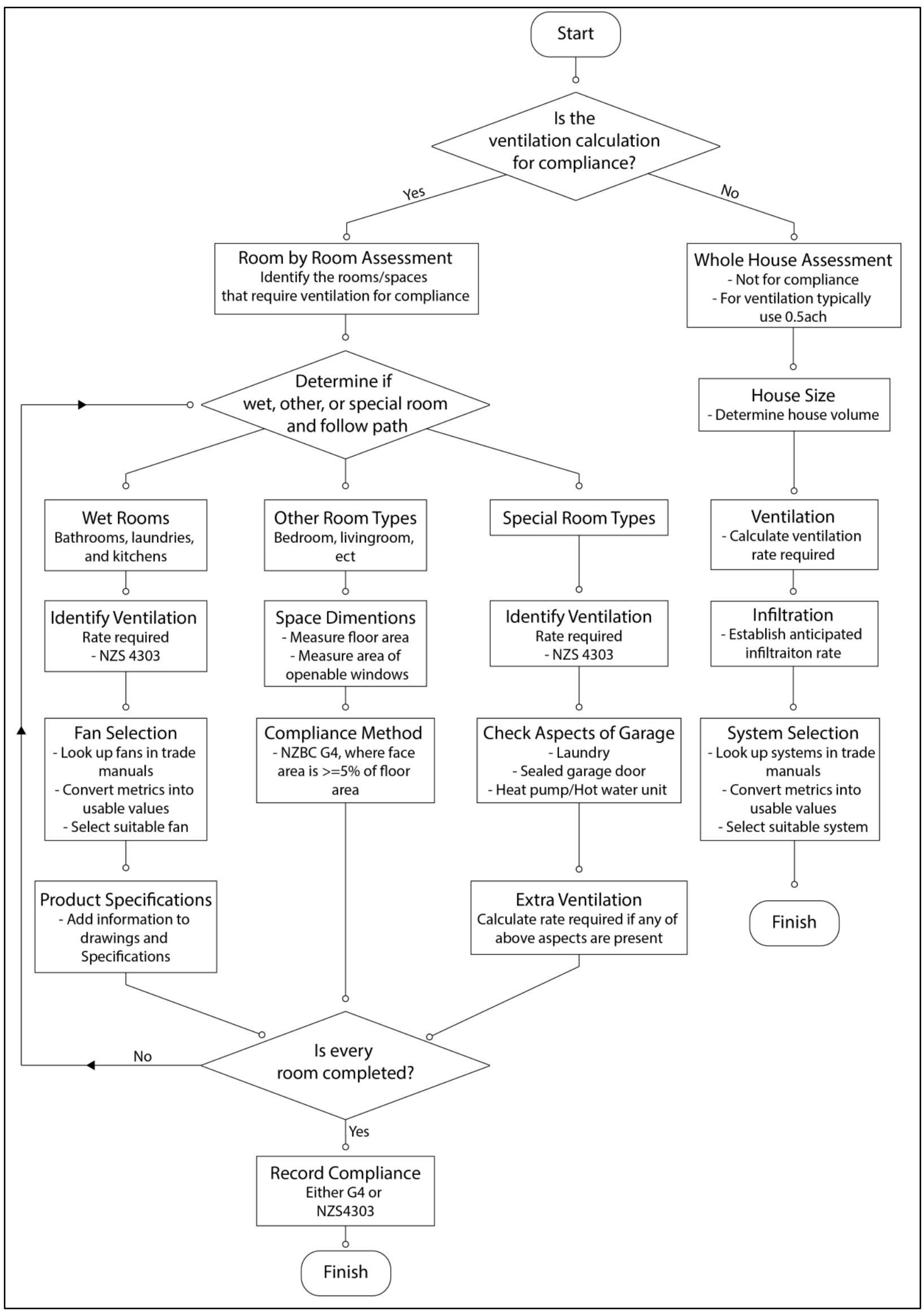

Figure 5: Process used in practice by Architects 


\subsection{Proposed Calculation Process}

From observations made in section

11.0 Practicing Calculation Process, a new process is determined that considers more variables. In addition to, compiling all the required information to calculate ventilation rates into one spread sheet. Below in section 12.1, a visual diagram of the new process is shown, this is elaborated on in the sections following.

\subsection{Workflow of sheets}

This workflow identifies all relevant tasks that must be completed in order to produce ventilation calculations, compliance information, and design advice. The image below the heading shows what the sheet looks like in the calculator. The process is broken into two main sections. First, the top section which can be completed in any order but all sheets must be completed in order to generate ventilation results. This leads on to compliance methods and ventilation systems, once again, either can be completed first. This workflow acts as a method to produce ventilation rates for a household room by room. While, adapting to different climates, levels of shelter, fenestration opening types, fenestration opening sizes, infiltration rates, room types, open plan spaces, and mechanical systems. 


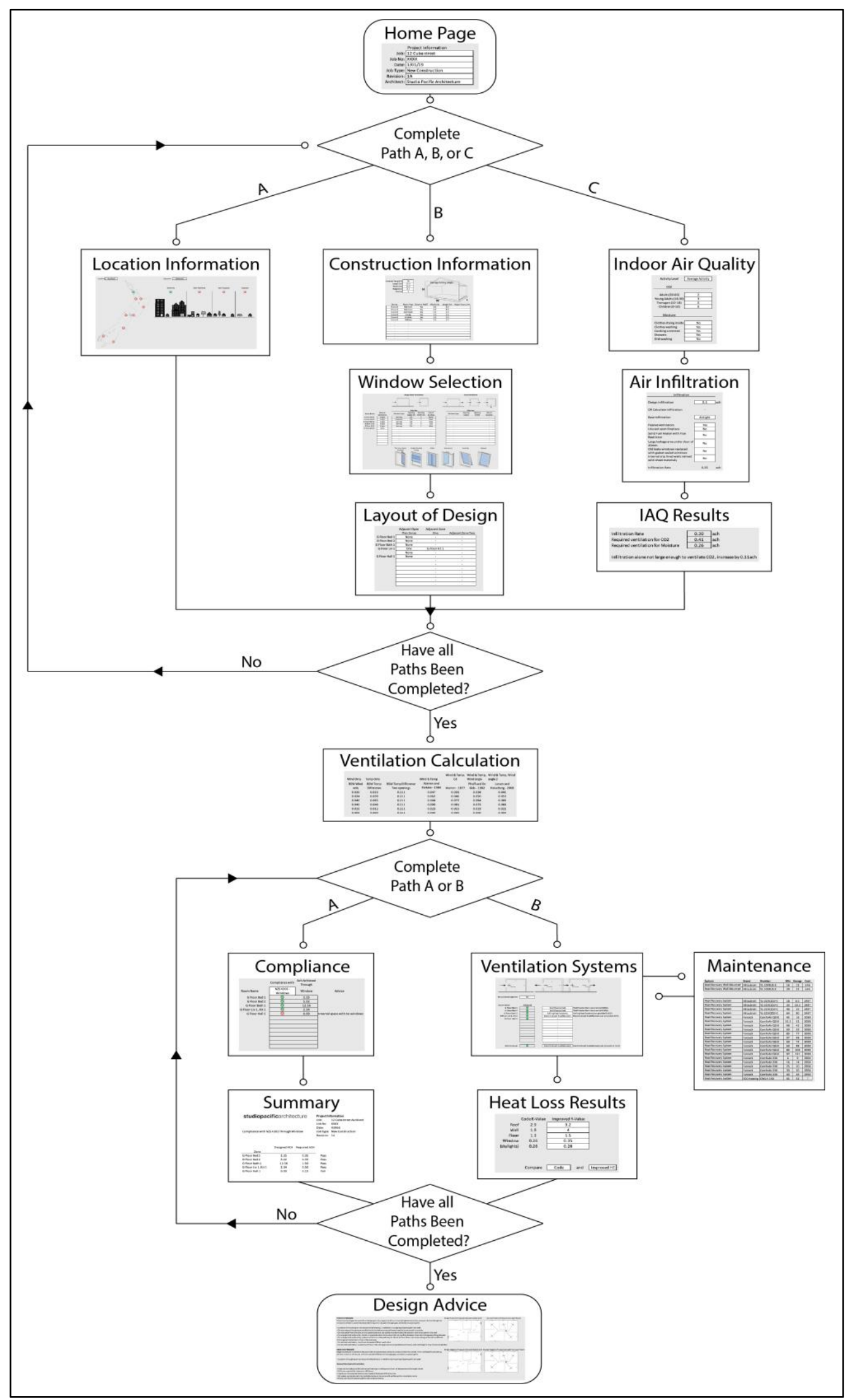

Figure 6: Proposed Process 
12.2 Homepage

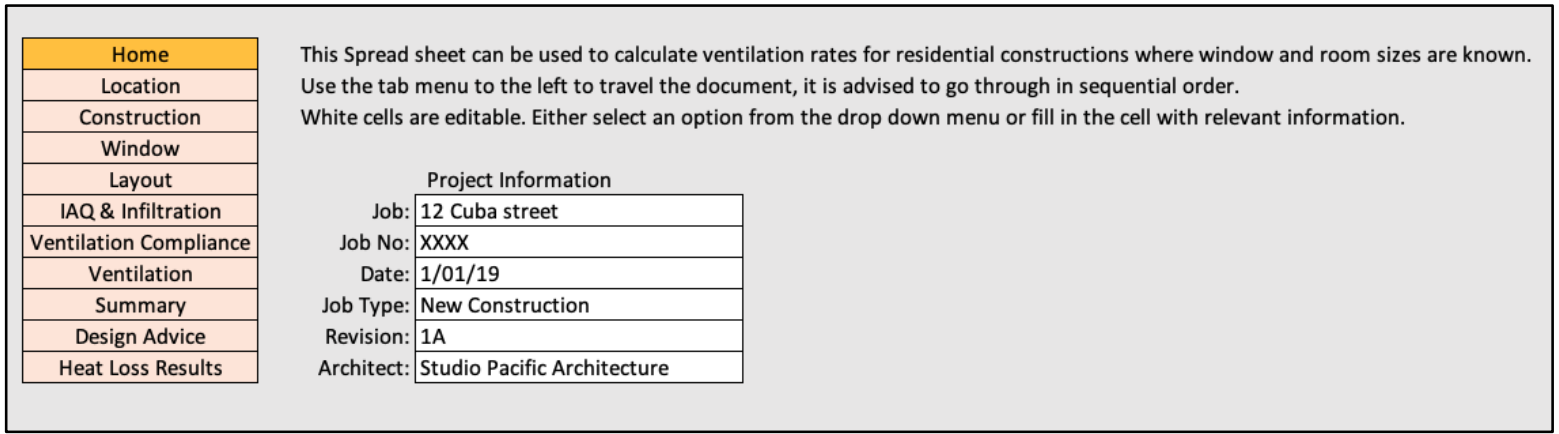

Figure 7: Homepage Sheet

The intent of a home page is to provide an introduction to what the calculator can provide and what sort of uses it has. In addition, project information is input on this page so users are clear on what project or revision is being calculated. The orange column on the left side of Figure 7 above, is used for navigation through the workbook and sets out the order sheets should be completed, this is present on each sheet which the current sheet highlighted.

The workbook has white cells throughout, which are the only cells that should be edited. A cell has two editable options, either select an option from a dropdown list or type in the cell with relevant information. Cells that either provide information about what needs to be input or the results, are greyed. The home tab is simple to use, a designer just has to fill in six cells with information about the current project.

With the simple initial page, no design inputs from architects have been made to either make process easier to use or improve aesthetics.

There are no calculations performed on the home tab, although all other tabs reference the project information so even when on another sheet the user can see they are working on the correct project or revision. 


\subsection{Location Information}

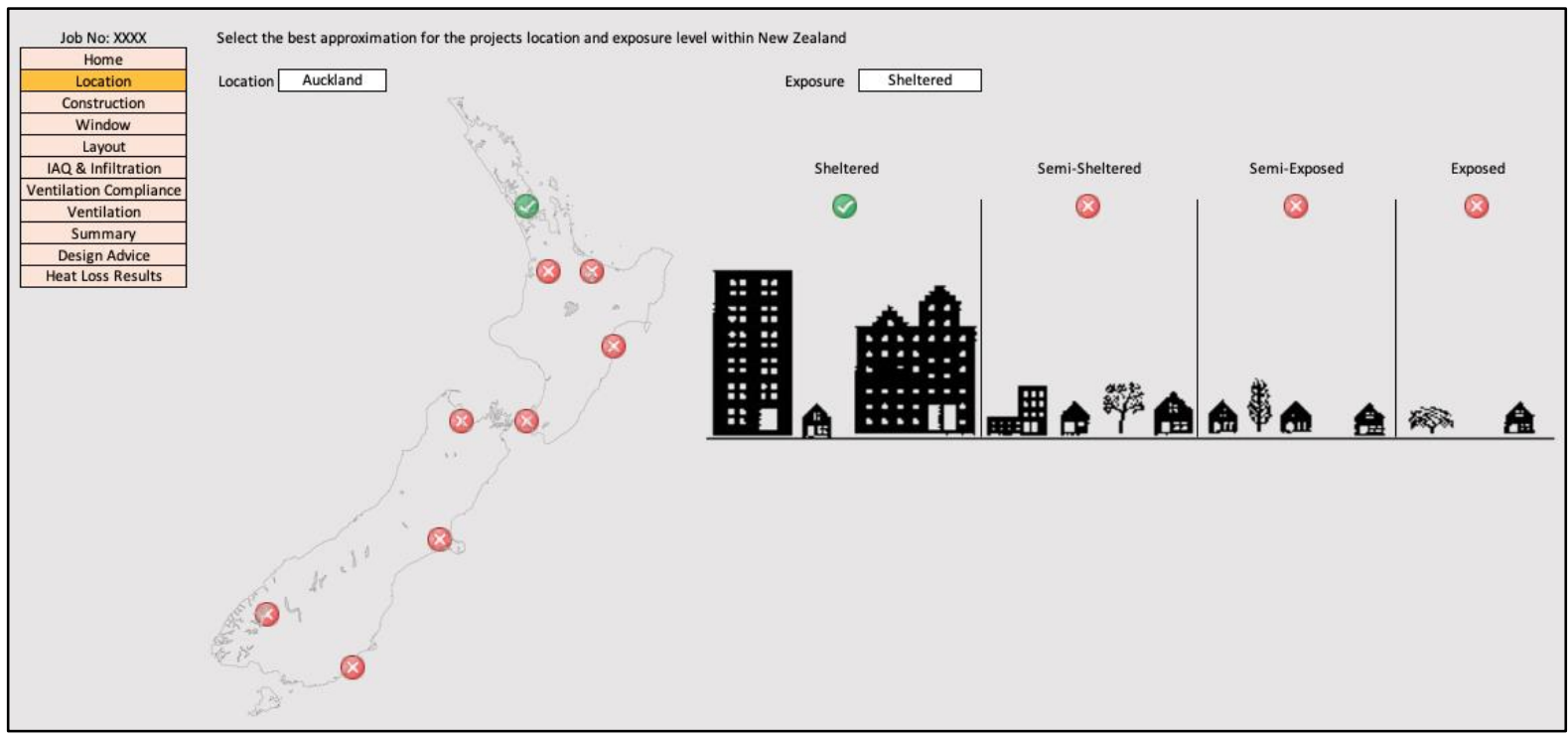

Figure 8: Location Information Sheet

The constructions location selection is an important part of the calculation process, as locations up and down New Zealand vary in temperature and wind levels. However, the climate in New Zealand is somewhat mild when compared to other countries therefore extreme differences are not seen. Whether information for the nine selected locations directly informs ventilation rates that can be achieved, this value is then altered depending on the selection of exposure level.

Where the project is located can be selected from the dropdown list, the closest approximation must be used if not in a major location. A visual feedback to confirm the correct location is shown in the form of a map with a single tick and multiple crosses. The same visual feedback process is used with the other dropdown list for exposure level.

Originally there was no visual feedback on this sheet just two selection boxes. Feedback from the architects improved this slide by suggesting this feature. While usability does improve, other problems can appear, such as images moving or cells reformatting. Within Excel images cannot be locked into a cell or "sent to back" behind the cells so that they can be selected.

Weather data for nine selected locations within New Zealand are sourced from the National Institute of Water and Atmospheric Research's (NIWA) .stat files. This file is compiled by taking the most average of each month over a thirty-year period and splicing them together. Therefore, the information tabled below is a yearly average of an average year.

Table 9: Information from weather data (NIWA)

\begin{tabular}{|c|c|c|c|}
\hline Location & Heating Degree Days (HDD) & Temp $\left({ }^{\circ} \mathrm{C}\right)$ & Wind Speed $(\mathrm{m} / \mathrm{s})$ \\
\hline Auckland & 1165 & 15.3 & 4.8 \\
\hline Christchurch & 2490 & 11.3 & 3.9 \\
\hline Napier & 1604 & 14.0 & 3.6 \\
\hline
\end{tabular}




\begin{tabular}{|c|c|c|c|}
\hline Nelson & 1912 & 12.9 & 3.2 \\
\hline Dunedin & 2657 & 10.7 & 4.4 \\
\hline Queenstown & 3121 & 9.5 & 3.1 \\
\hline Rotorua & 2146 & 12.2 & 3.5 \\
\hline Hamilton & 1710 & 13.5 & 2.3 \\
\hline Wellington & 1930 & 12.8 & 7.1 \\
\hline
\end{tabular}

These locational weather values are used to calculate the heat loss and ventilation rates. Heating degree days is a metric used to count how many degrees the average temperature for each day in a year is below a set temperature. Heating degree days as shown above is set to a base of $18^{\circ} \mathrm{C}$. These values are referenced to from the heat loss tab, how they are used in a calculation is spoken to there. The average temperature and wind speed for a location are used in the variety of ventilation calculations proposed earlier.

Wind speed varies depending of the buildings height in addition to the surrounding terrain. This varied wind speed $V$ shown in Formula 16 below, is calculated at a height $\mathrm{z}$ in relation to the meteorological wind speed at a height of $10 \mathrm{~m} \mathrm{~V} \mathrm{~V}_{\text {met. }}$. While, $\mathrm{K}$ and a are constant values depending on the table below (CIBSE, 1997).

$$
V=K z^{a} V_{m e t}
$$

Table 10: Variables of windspeed for different terrain types

\begin{tabular}{|l|c|c|}
\hline Terrain & K & a \\
\hline Open flat country & 0.68 & 0.17 \\
\hline Country with scattered wind breaks & 0.52 & 0.20 \\
\hline Urban & 0.35 & 0.25 \\
\hline City & 0.21 & 0.33 \\
\hline
\end{tabular}

When an exposure level is selected the relative constants and information that is input on the coming sheet is used to calculate the reduced average wind speed for that location. This process gives a more accurate interpretation of ventilation rates due to natural ventilation.

Future work for this sheet would be in its design. An interactive map that let the user click on the map for where the project is located and an automated system to choose a weather file from the closest available location would make the workflow faster and easier. 


\subsection{Construction Information}

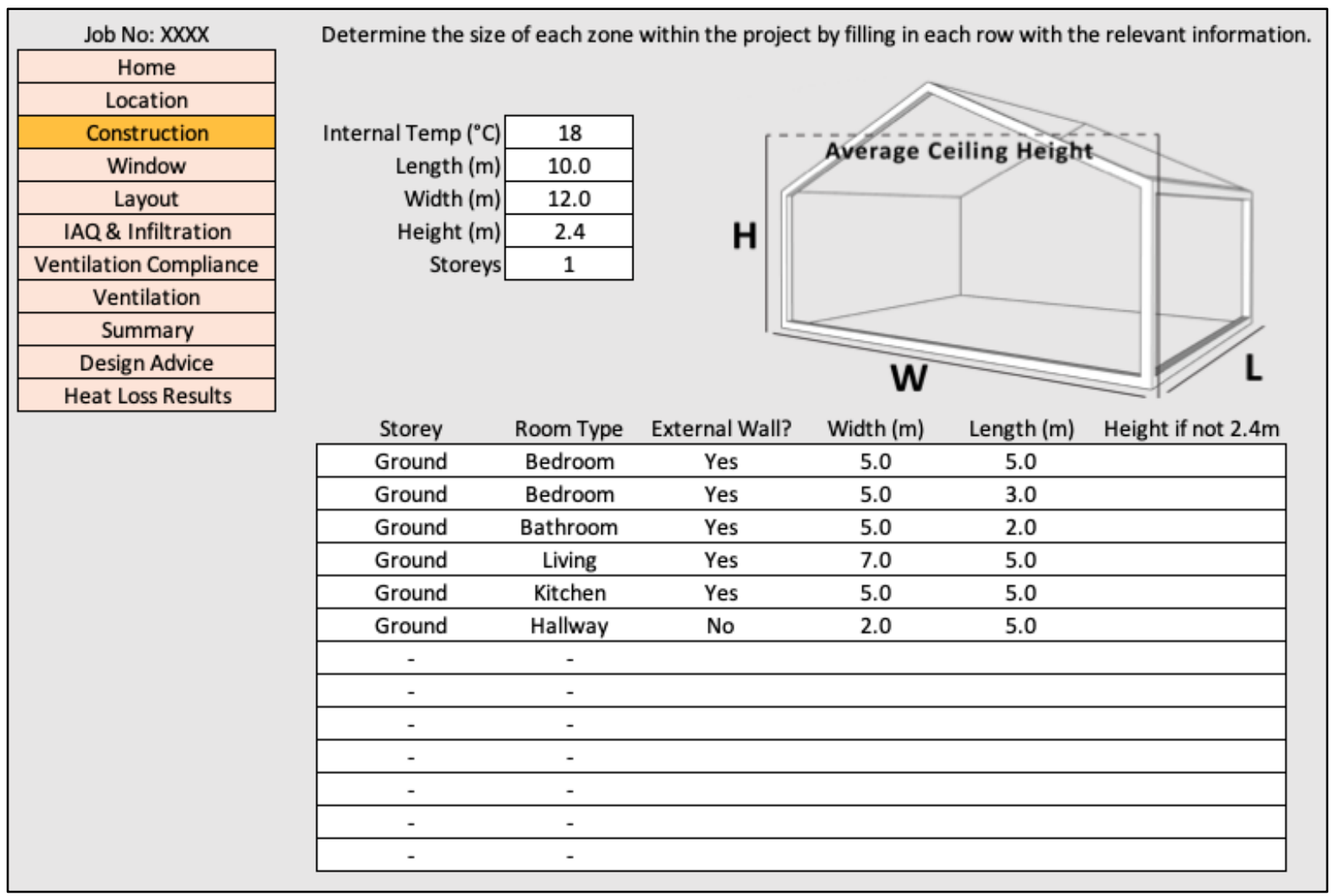

Figure 9: Construction Information Sheet

The intent of a construction sheet is to layout the buildings overall dimensions and then the dimensions of each internal zone. In addition, informing the calculator about other factors relating to each room.

By filling in the top set of boxes the size of the building is known and the base temperature is set. To add a room, the storey of which it is on needs to be selected, this enables the other boxes to be filled in across the page. Each line is a new zone of the building and is intended to be one specific room type. If there is an open plan space of kitchen and dining these need to be split up so specific ventilation requirements can be set. A simple dropdown list of either Yes or No is given for the question of, is there an external wall on this zone. By selecting Yes, the calculation processes run normally as there can be external windows. Whereas, if the selection is No the calculator is informed that this space doesn't have to meet specific codes and requirements. The last cells are where zone dimensions are input. However, the cell for height should only be used if that zone has a different ceiling height as it overrides the default value.

In the initial revisions of the calculator, there was a more manual input to distinguish the rooms by number. This process was found to confuse the user and was subsequently made to be automatically done in the background. Another useful input from a practicing architect was make the room names abbreviated, as well as changeable, shown below in Figure 10. This meant there is a consistent naming system, and if something changes it can be updated from one place. 


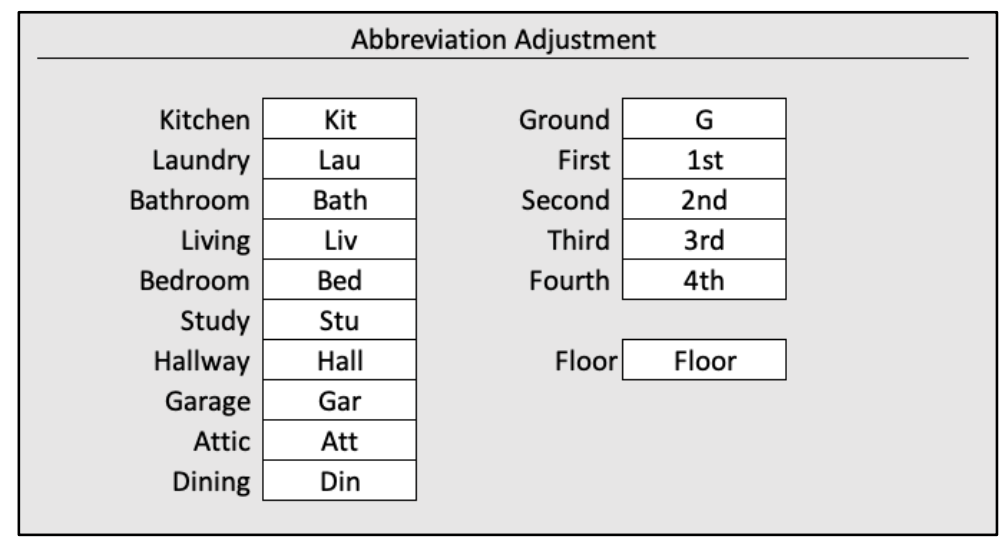

Figure 10: Abbreviation Adjustment Section

By making some sections unavailable until previous dropdown lists have been used errors are reduces through a step by step process. While, in previous iterations zones could be set on any possible storey, they are maxed at the predetermined number of storeys set in the upper section of the sheet.

Some calculations are performed on this sheet, additionally, the room information is referenced throughout the workbook. Zone areas, volumes, and names are calculated. The area and volume is simple multiplication while the names of each room have to be concatenated together using the abbreviated form. Basic error messages have been built into the sheet so that if information has been left out or is incompatible the user is aware. An example of this is if the floor area of the overall house and the zones don't match a red message saying "areas don't match" appears.

A limitation of this sheet is that zones can only be input as squares or rectangles, although, it is possible to "join" these which is explained in the next section, 12.6 Layout. A future adaptation to this sheet would be to implement ventilation calculations for any shape or size space. 
12.5 Fenestration Opening Selection

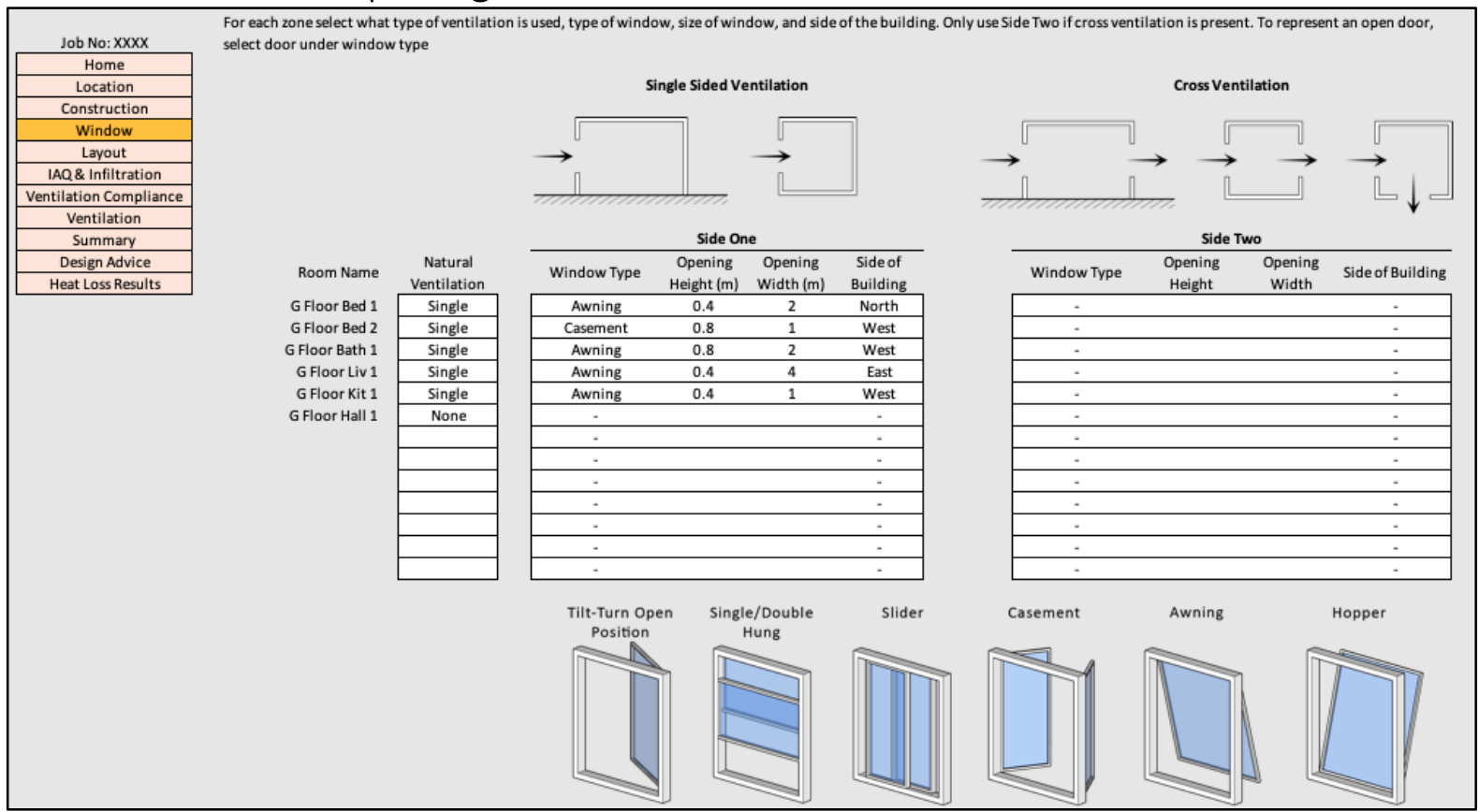

Figure 11: Window Selection Sheet

The window sheet is used to apply specific windows or doors to the zones that were created on the last sheet so that ventilation rates can be calculated using either cross or single sided ventilation.

During the calculation process of the spread sheet the type of natural ventilation needs to be defined from single, cross, or none. This informs the calculator whether it is expecting one, two, or no windows. The side of the building on which the windows would be is also selected, this helps in calculating ventilation rates, in addition to checking inputs are correct. As explained in section

5.4 Openable Windows, different styles of window have different efficiencies for wind penetration. In the calculation process, a user inputs window dimensions and selects a style, the calculator then generates the effective window area that ventilation can occur through. Designers can select the window style based on the appearance or the air flow effectiveness. If cross ventilation had previously been selected, the calculator allows the user to enter information on side two, which in turn asks the same questions.

This sheet in particular has been altered many times trying to refine the usability of it, there were many other selection options that helped the calculator but not the user. Most of these have been designed out or built into the background. After it was realised that some architects did not know what every window type was, images of them were added, this greatly improved usability. Images of single sided ventilation and cross ventilation are also present to visualise the differences, along with illustrating the different configurations they can be in.

Openable window area is calculated from the inputs and reduced to the effective window area depending on the window type selected. This information is used later in the ventilation calculations. If cross ventilation has been selected, the pressure difference $(\Delta C p)$ 
is calculated, this is dependent on what sides of the building the selected windows are on. Like with the previous sheet, error messages have been built into the calculator that can pick up simple user errors.

Future additions to this sheet would be to implement more doors with their own selection option so that at a glance a door can be seen as a door and not a large window. Additionally, working into the spreadsheet that if two windows are selected that cross ventilation is present and if there is only one then its single sided would negate the need to have the first drop down selection list.

A limitation is that only one scenario can be tested at a time. This means if a user wants to test ventilation rates with one window open and then two, a manual change of the window selection has to be completed. Additionally only two windows can be added as this is all the formulas can account for.

\subsection{Layout of Design}

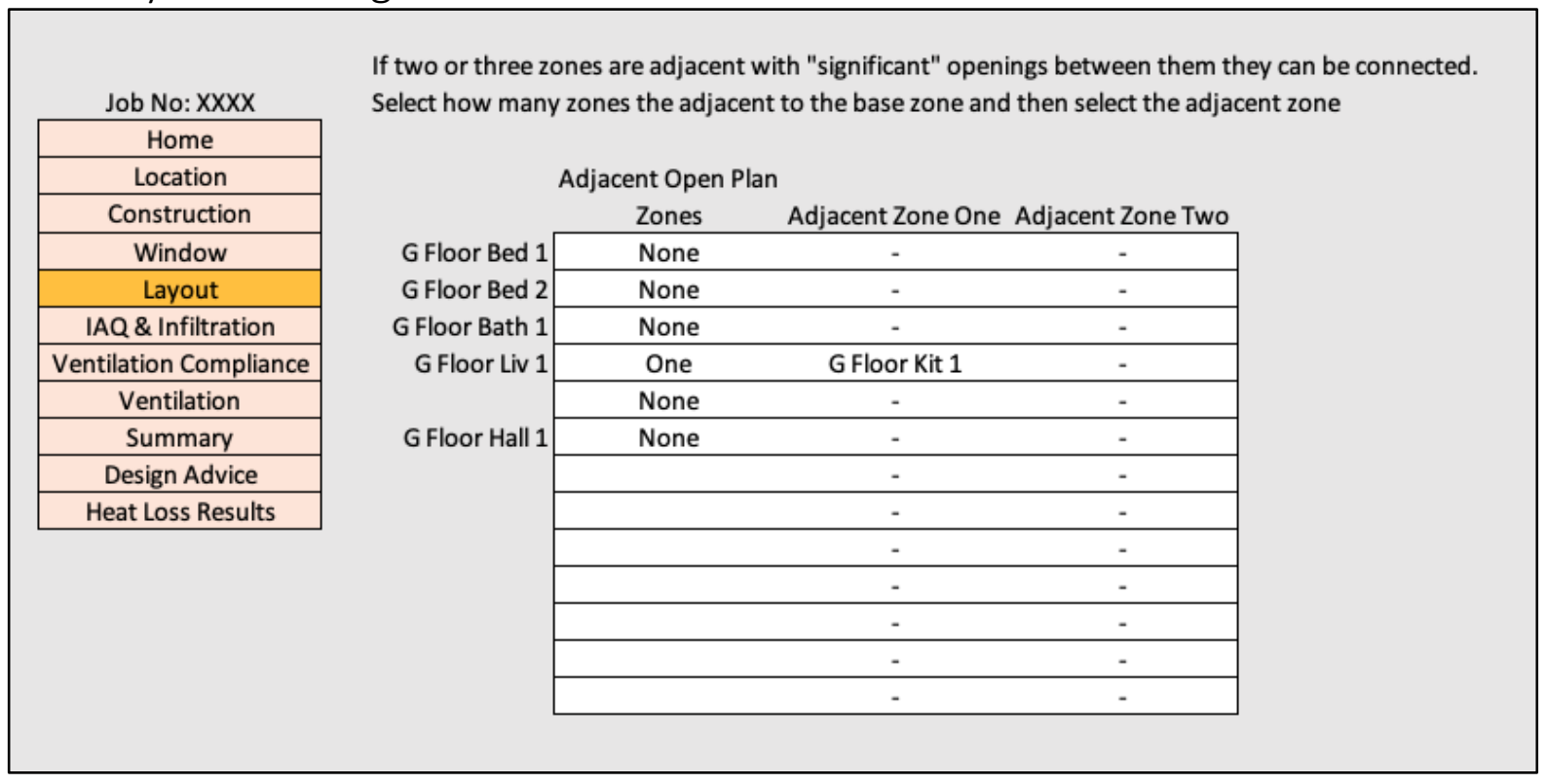

Figure 12: Layout Sheet

The layout sheet allows users to connect zones to each other if there are open plan areas within a house. All aspects about the spaces are combined to form a new zone with a concatenated name.

By selecting an amount of adjacent zones the calculator is expecting inputs in the next one or two columns. If a zone has one connecting area, only the adjacent, zone one column allows any inputs to be selected. A dropdown list provides the rooms that have not already been linked to zones making sure that no duplicates could appear. Once an adjacent zone is selected it becomes unavailable in the list on the left side.

As one of the more complex sheets in the workbook a lot of work has gone into keeping the interface simple. However, with minimal suggestions from the architects on how to make 
this page more usable it hasn't changed from the original design, although, there are some ways it could be simplified even more.

Although there are a lot of background calculations to make a simple interface work effectively, all this sheet is doing is combining values from different zones into one zone and shortening the name.

Future work can be done reducing the sheet to just the adjacent zone options, the calculator could work out that a user has selected two different zones as inputs and know to combine them all. This has not currently been completed due to time restraints.

A limitation for this sheet is that only three zones can be connected together. This amount is built into the calculator and could be increased with a lot of time and work.

\subsection{Indoor Air Quality}

\begin{tabular}{|c|c|c|}
\hline Job No: XXXX & \multirow{2}{*}{\multicolumn{2}{|c|}{$\begin{array}{l}\text { Select an activity level suitable for the household, the number of } \\
\text { occupants, and what moisture causing activities are completed. }\end{array}$}} \\
\hline Home & & \\
\hline Location & \multirow{4}{*}{ Activity Level } & \multirow[b]{2}{*}{ Average Activity } \\
\hline Construction & & \\
\hline Window & & \\
\hline Layout & & \\
\hline $\mathrm{IAQ}$ & $\mathrm{CO} 2$ & \\
\hline Infiltration & \multirow{4}{*}{$\begin{array}{l}\text { Adults }(30-60) \\
\text { Young Adults (18-30) } \\
\text { Teenagers }(10-18) \\
\text { Children }(0-10)\end{array}$} & 2 \\
\hline IAQ Results & & 3 \\
\hline Compliance & & 0 \\
\hline Ventilation & & 0 \\
\hline Summary & & \\
\hline Design Advice & Moisture & \\
\hline Heat Loss Results & & \\
\hline & \multirow{5}{*}{$\begin{array}{l}\text { Clothes drying inside } \\
\text { Clothes washing } \\
\text { Cooking unvented } \\
\text { Showers } \\
\text { Dishwashing }\end{array}$} & No \\
\hline & & Yes \\
\hline & & Yes \\
\hline & & Yes \\
\hline & & No \\
\hline
\end{tabular}

Figure 13: Indoor Air Quality Sheet

Measuring or calculating the Indoor Air Quality (IAQ) for a house or even a single space can be done based on quantities of different pollutants. Rating the air quality is based on the concern of having to many pollutants causing stale air or an unhealthy internal environment. Carbon Dioxide, moisture vapor, and particulate matter are of most concern in a residential household, and can all be expelled or filtered through ventilation. This sheet is used to understand how much $\mathrm{CO}_{2}$ and moisture is produced and what causes moisture production. 
The user selects an appropriate activity level that the house hold performs at. Each level equates to a different activity level. Low is at $55 \mathrm{~W} / \mathrm{m}^{2}$, average at $60 \mathrm{~W} / \mathrm{m}^{2}$, and medium at $65 \mathrm{~W} / \mathrm{m}^{2}$, based off of Sharpe et al. (2015). Because these values are an approximation over an entire day they are not dramatically different and are used to distinguish levels of activity of an average family. Furthermore the amount of occupants in each age bracket need to be selected. This calculates the $\mathrm{CO}_{2}$ produced from each person over an hour. Last a series of questions relating to sources of moisture that can appear in a household. Each of the questions add an associated value of moisture to the room that can be seen in Table 12.

The calculations performed on this sheet relate to metabolic rates, production of $\mathrm{CO}_{2}$, and production of moisture. The metabolic rate is the standard way of recording how much heat is generated from an average human body while performing different activities. The metabolic rate varies with activity in a household, while sleeping the heat generation is $40.7 \mathrm{~W} / \mathrm{m}^{2}$ of body surface area, seated is $58 \mathrm{~W} / \mathrm{m}^{2}$, and walking is $116 \mathrm{~W} / \mathrm{m}^{2}$ (CIBSE, 2008). This is assuming the average body surface area for adults is $1.8 \mathrm{~m}^{2}$. In Sharpe et al. (2015), $60 \mathrm{~W} / \mathrm{m}^{2}$ is used as an approximation to capture the mix of non-sleep activity and the various phases of sleep activity. When changing the activity level for the occupants in the calculator, the metabolic rate is essentially increased, which through the calculation process explained below generates more $\mathrm{CO}_{2}$.

Carbon Dioxide is produced by the human metabolism and exercise, at differing rates depending on a person's sex, age, height, and weight. Work by Persily and Jonge (2016) has gone into describing $\mathrm{CO}_{2}$ generation estimations, this breaks up the formulation and describes constant values. To closely represent $\mathrm{CO}_{2}$ generation of a household the category of people needs to be split into age brackets. Using the metabolic rates described in the section above, Persily and Jonge's calculation is able to be performed to calculate the $\mathrm{CO}_{2}$ production in $\mathrm{I} / \mathrm{h}$ for an average person in an age bracket.

Persily and Jonge's $\mathrm{CO}_{2}$ calculation is shown in formula 17 below where the basic metabolic rate (BMR) is calculated by multiplying a person's mass by variable factors, or using the chart in their paper. The $M$ in the formula is a metabolic value, this is the metabolic rate divided by 58.2 which is average work.

$$
V_{C O 2}=B M R * M * 0.000484
$$

Table 11: Metabolic Values

\begin{tabular}{|l|c|}
\hline Activity Level & Metabolic Value (M) \\
\hline Low & 0.945 \\
\hline Average & 1.031 \\
\hline Medium & 1.116 \\
\hline
\end{tabular}

Moisture within the whole house is calculated using values for water vapor production from Bishop (1987). These sources and the amount generated are averaged over the period of a day. 
Table 12: Moisture Generation, Bishop (1987)

\begin{tabular}{|l|c|}
\hline Source & Average (l/day) \\
\hline Clothes drying, unvented & 12 \\
\hline Clothes washing & 2 \\
\hline Cooking, unvented & 2.2 \\
\hline Showers, each & 0.2 \\
\hline Dishwashing & 0.5 \\
\hline Human metabolism, at rest & 0.1 \\
\hline Human metabolism, average & 0.2 \\
\hline Human metabolism, hard work & 0.3 \\
\hline
\end{tabular}

The calculator totals the values for which Yes is selected, together with the total from multiplying the number of occupants by the relative activity level for moisture production.

Future work on this section would go into quantifying particulate matter levels within households. Particulate matter are the particles of dust, water, and pollution from natural or manmade processes that are on the microscopic scale. They are used as a common indicator for the level of air pollution as they have the potential to affect more people than any other pollutant. The World Health Organisation (WHO) have guidelines on how much particulate matter should be in the air to have no observable damage to health. There are two different sizes that are specified $\mathrm{PM}_{2.5}$ and $\mathrm{PM}_{10}$, these refer to particles that are less than 10 microns in diameter and particles that are less than 2.5 microns in diameter (WHO, 2018). Air quality measurements are reported in terms of daily or annual mean concentrations below.

Table 13: particulate matter

\begin{tabular}{|c|c|c|}
\hline Size & Annual Mean & 24-Hour Mean \\
\hline 2.5 microns or less & $10 \mu \mathrm{g} / \mathrm{m}^{3}$ & $25 \mu \mathrm{g} / \mathrm{m}^{3}$ \\
\hline 10 microns or less & $20 \mu \mathrm{g} / \mathrm{m}^{3}$ & $50 \mu \mathrm{g} / \mathrm{m}^{3}$ \\
\hline
\end{tabular}

There are also other pollutants that can affect the indoor air quality but are harder to determine the source concentrations for a household. Ozone $\left(\mathrm{O}_{3}\right)$, Nitrogen Dioxide $\left(\mathrm{NO}_{2}\right)$, and Sulphur Dioxide $\left(\mathrm{SO}_{2}\right)$ are also listed by the World Health Organisation as being harmful. Sources for these are mainly volatile organic compounds (VOCs), solvents, power generation, or burning fossil fuels. 
12.8 Air Infiltration

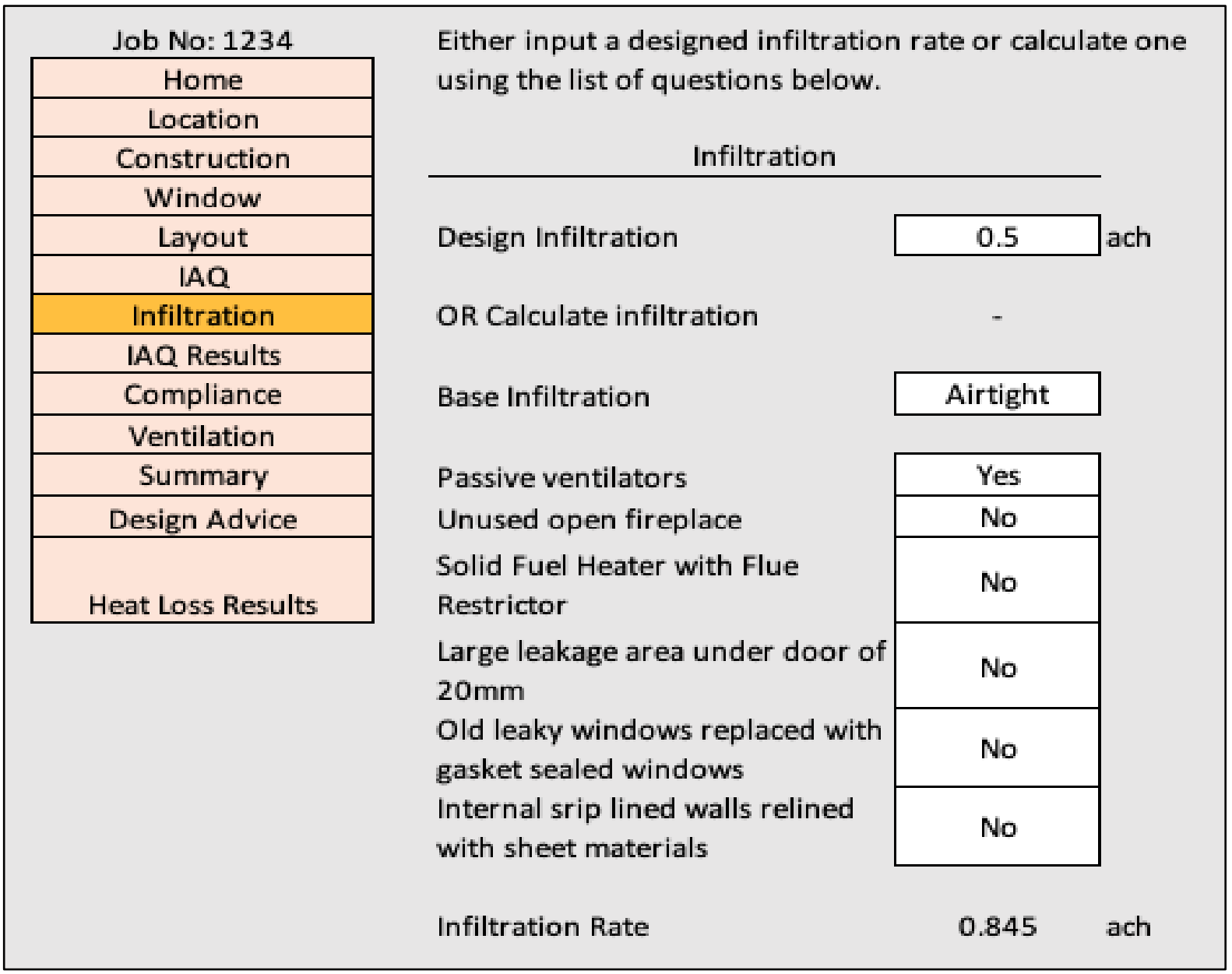

Figure 14: Air Infiltration Sheet

The infiltration sheet is designed to let the user set a infiltration rate for a house. Two methods are given, one is to input a design infiltration rate in $\mathrm{ACH}$. While the second is to answer questions about an existing house. More information about this method is described in section 5.1 Base Infiltration.

Infiltration impacts mainly compliance with NZS4303, as it boosts the base rate of ventilation for a house in addition to the heat loss calculation results. With a simple design and layout, the main advice was to split this section up from the previous section and the proceeding one so that ideas and inputs don't get mixed up.

With the design infiltration input overriding the questionnaire path, both inputs can't be used. The associated values with each question increase the overall infiltration rate of the house. A base infiltration value is set off of the first dropdown selection, these values can be seen in Table 1 in section 5.1 Base Infiltration. The other values which also come from Bassett (2001) report are below in Table 14: Infiltration Correction (Bassett, 2001). The resulting value is then adjusted by two factors. Firstly, a regional factor of either $0.9,1.0$, 1.1 , or 1.3, dependent on the location chosen in section 12.2. Then, a multiplying factor relating to the wind exposure level, of either $0.5,0.7,1.0$, or 1.3 . 
Table 14: Infiltration Correction (Bassett, 2001)

\begin{tabular}{|l|c|}
\hline Questions & Influence on ACH \\
\hline Addition of passive ventilators to windows & 0.2 \\
\hline Unused open fireplace & 0.1 \\
\hline Solid fuel heater with flue restrictor & 0.05 \\
\hline Large leakage area under door of $0.02 \mathrm{~m}^{2}$ & 0.1 \\
\hline Old leaky windows replaced with gasket sealed windows & -0.2 \\
\hline Internal strip lined walls relined with sheet materials & -0.1 \\
\hline
\end{tabular}

A limitation to calculating a houses infiltration rate is to which all the factors are known or not. If there are too many unknowns, the calculation becomes to inaccurate and it may be better off to set the design rate at a reasonable level.

12.9 IAQ Results

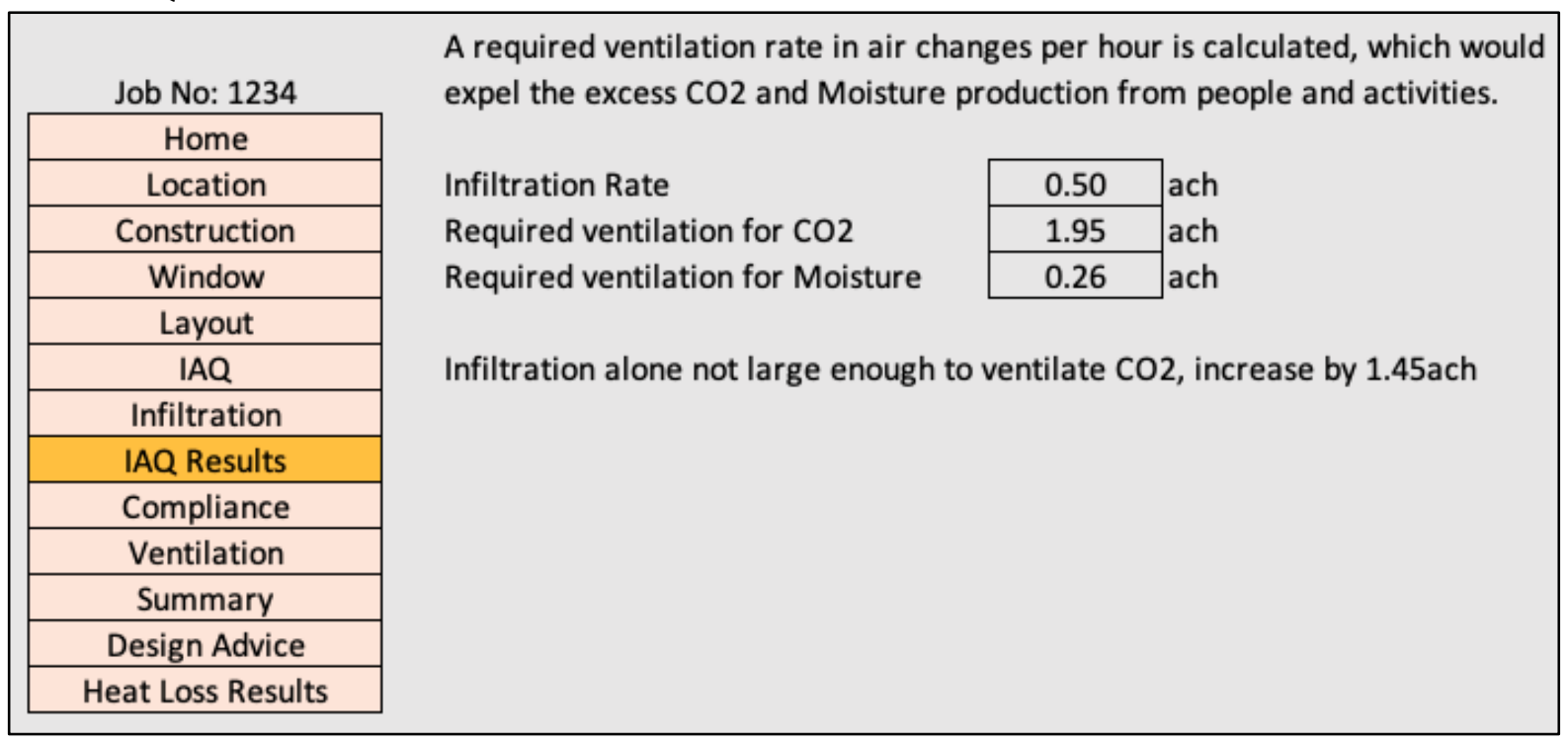

Figure 15: IAQ Results Sheet

The Intent of this page is to report on the indoor air quality in terms of $\mathrm{CO}_{2}$ and moisture, while providing useful incite to whether the space is preforming effectively or not. What the sheet is telling the user is, the required ventilation rate to expel the internally produced $\mathrm{CO}_{2}$ and moisture, along with, the infiltration rate of the house. From these values a suggestion is made, which is the amount only infiltration needs to increase to combat the production.

This sheet does not contain any input, it only displays information from other sheets and provides calculations.

The result from the calculation defined in section 8.6 is the volume of $\mathrm{CO}_{2}$ produced in $\mathrm{l} / \mathrm{s}$. Using formula 18 below from Adamovsky (2018), the ventilation rate required to combat $\mathrm{CO}_{2}$ generation, $\mathrm{V}_{\mathrm{s}}$, can be calculated. $\mathrm{CO}_{2}$ max is defined as $1000 \mathrm{ppm}$, while $\mathrm{CO}_{2}$ out is $400 \mathrm{ppm}$. The amount of ventilation required to combat the production of $\mathrm{CO}_{2}$ is calculated from this based on the limit set in NZS 4303. The limit of 1000 parts per million (ppm) is set not for health reasons, but for odour levels in the air. 


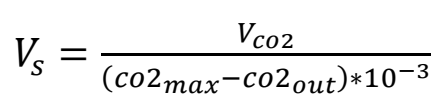

After calculating the $V_{s}$ rate for each person in the house the total supply ventilation need can be divided by the houses volume to get the air changes per hour required.

Future work would involve calculations that would change based on location using local weather data and $\mathrm{CO}_{2}$ levels.

\subsection{Compliance}

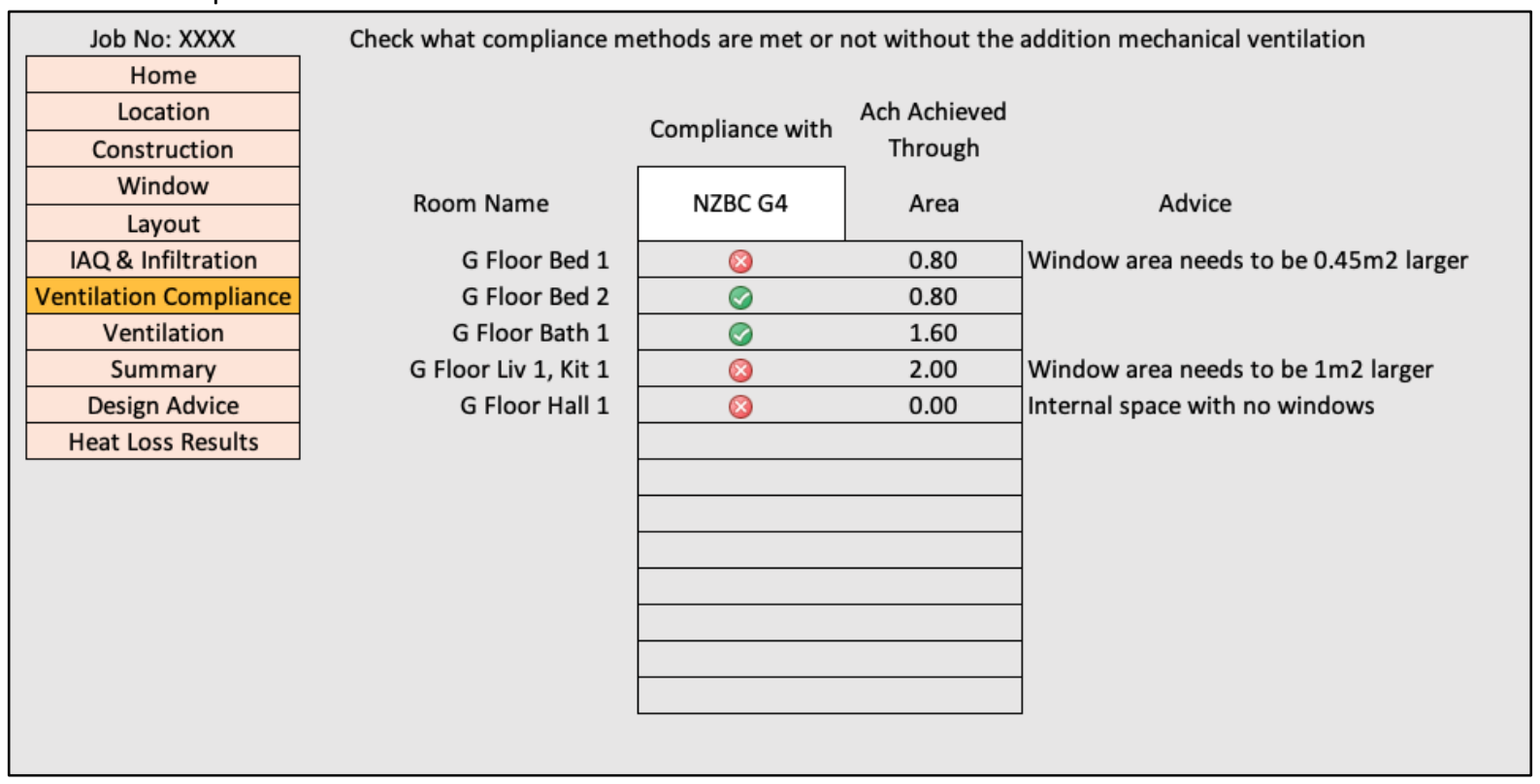

Figure 16: Compliance Sheet

Having the user be able to check what compliance methods pass or fail for each room helps them understand how a space is performing. Automatic advice stating how to improve and pass is produced through the calculation process for each zone that fails. Users can check compliance against the New Zealand Building Code section G4, or New Zealand Standard 4303:1990 Ventilation for acceptable indoor air quality.

On this sheet there is only one editable cell, it has a dropdown menu where the different codes can be seen and selected. The options are NZBC G4, NZS 4303 - Windows, or NZS 4303 - Infiltration. These standards use different methods to prove compliance, the difference between windows and infiltration is that the windows are assumed to be open for windows and closed for infiltration. Therefore, Infiltration always performs the worst.

The design input from architects for this sheet to make it simpler was to reduce the amount of drop down selections to the minimum required. This enabled only selecting the standard to which compliance was being looked, while everything changes relating to that cell.

\section{Ventilationcaloulationsarenotperformedonthispagebuttheresultsarereferencedto.}

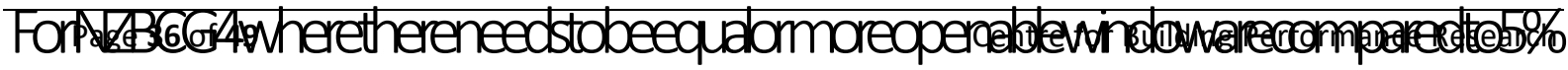
ofthefloorsarea,asimplecalaulationcanbedonetoseeifitiseithertneomotffazone 
passesthisstatementitisseenwithaticknexttotheroomname.NRS4304requires ventilation rates to be calculated, these are explained in section 12.16 Ventilation Calculations, the ventilation rates are compared to ventilation requirements for that room type and given a pass or fail like with G4. Requirements for passing the minimum code level can be seen in section 8.0 Ventilation Systems

Different ventilation systems provide differing amounts of air per second, a range of these have been compiled from manufactures so that bands of effectiveness can be seen.

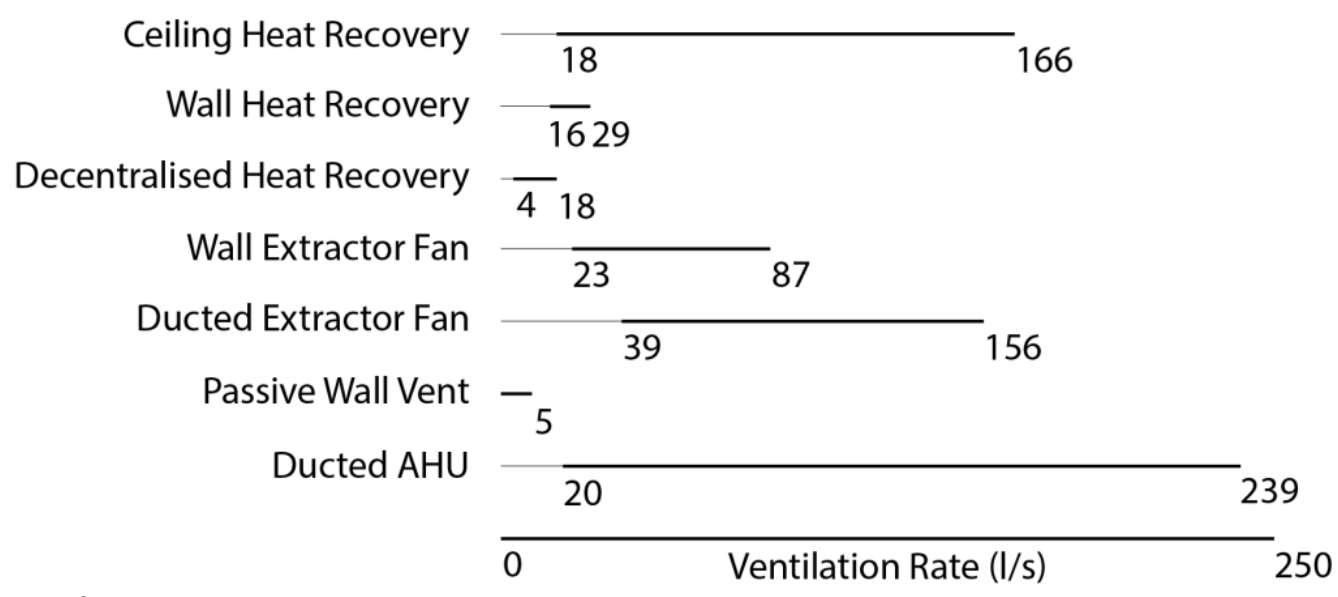

Figure 3: User free Ventilation systems

The lowest providable ventilation is from the only non-mechanical system, passive wall vents, or trickle vents. This strategy is suggested most often when analysing single rooms as they tend to only need a small amount of additional ventilation. For a bathroom or a kitchen where rates are higher, some of the other systems come into effectiveness. When looking at the house as a whole the larger ventilation rates become more useful as a single system can provide the necessary rates. A table of all the current systems that are in the sheet can be seen in Appendix One.

9.0 Codes. 
12.11 Ventilation

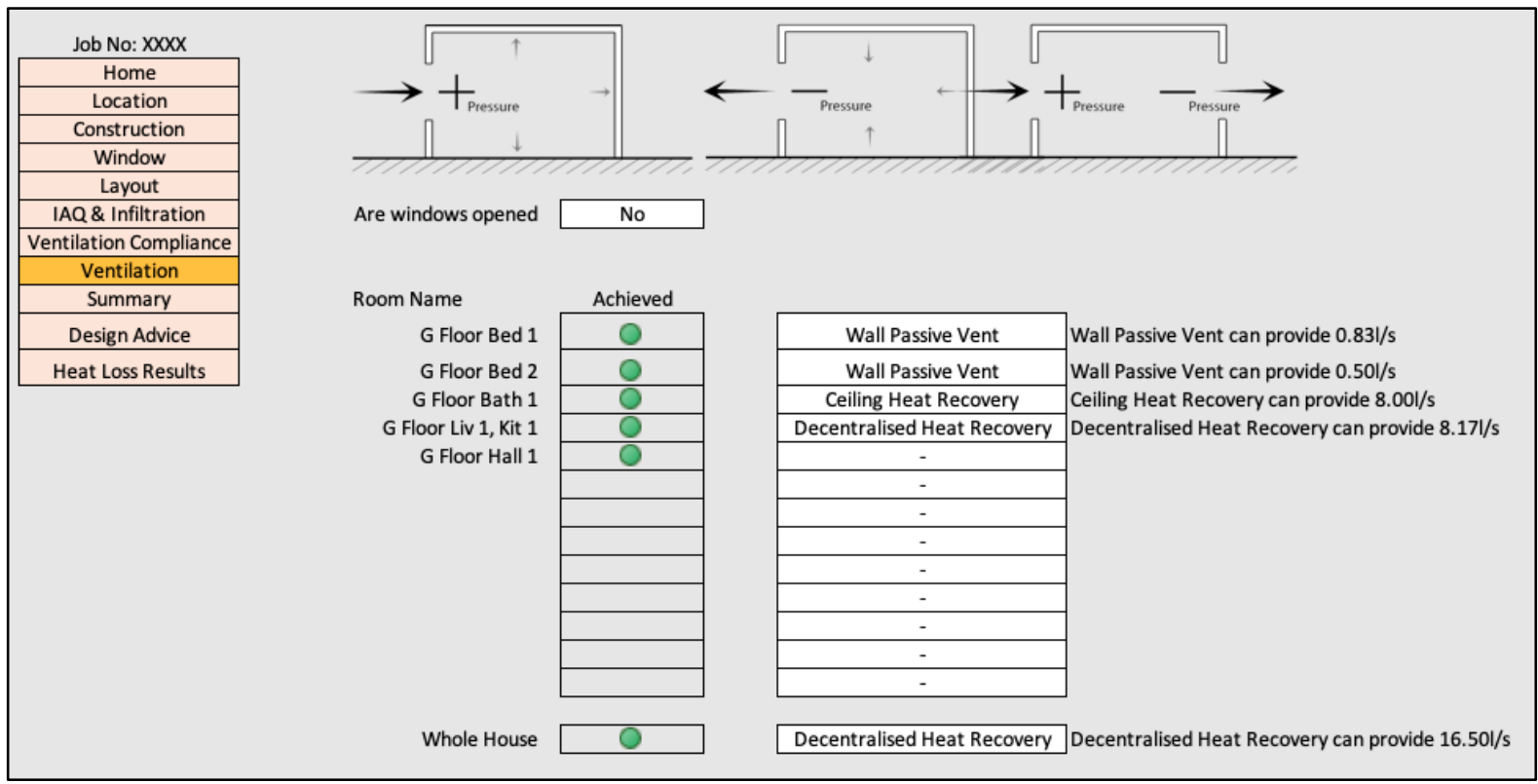

Figure 17: Ventilation Sheet

The ventilation sheet is used to identify possible ventilation systems that can achieve the ventilation rates required to meet NZS 4303 when windows are open or closed.

Selecting if windows are opened or not, changes the ventilation rates achieved, therefore changing the suggested systems that can be implemented to for fill the extra requirement. Once the windows position has been selected suggested systems appear in the dropdown menu based off of the performance bands in section 8.0 Ventilation Systems can either be designed for each room or for the whole house. If the whole house option is used it is assumed that there would be sufficient gaps under doorways of at least $20 \mathrm{~mm}$ to let air flow through.

Design input has changed this sheet from a system that generated selectable ventilation rates, which a user would choose from to find a rate that achieved the requirement to what it is now. This improvement means architects don't have to research what system could be used. In addition, a user can also see the ventilation rate required, so if a client specifies a different system, one can be found that meets the minimum.

Like with the compliance sheet, this one compiles useful information that is calculated elsewhere. It checks what ventilation rate is required and then shows the systems providable bands that the ventilation rate value fits in.

Future work for this sheet would be analysing the differences between systems. Through suggesting a hierarchical list of the systems that are more energy efficient, cost less upfront or cost less overtime, the user would be able to design closer to their client's needs.

As the list of systems are not automatically updated the limitation of the sheet is that systems never get updated. If a new system becomes available it has to manually be added on the maintenance page. 


\begin{tabular}{|c|c|c|c|c|}
\hline \multirow{2}{*}{\multicolumn{3}{|c|}{ studiopacificarchitecture }} & \multicolumn{2}{|c|}{ Project Information } \\
\hline & & & Job: & Test Wellington \\
\hline & & & Job No: & 1234 \\
\hline & & & Date: & 43466 \\
\hline \multirow{2}{*}{\multicolumn{3}{|c|}{ Compliance with NZBC G4 Through Area }} & Job Type: & New Constructior \\
\hline & & & Revision: & $1 \mathrm{~A}$ \\
\hline & Window (m2) & Floor (m2) & & \\
\hline Zone & & & \multicolumn{2}{|c|}{ Percentage } \\
\hline G Floor Bed 1, Bed 2 & 1.00 & 25.00 & 0.04 & Fail \\
\hline
\end{tabular}

Figure 18: Summary Sheet

A summary sheet provides a compliance document for the architects to submit with their consent application. It displays what method is being used along with broken down calculations on how each value has been worked out so a consent officer can check the working.

All this sheet does is display information that is found on other sheets in a concise document that can be printed on A4.

As the summary sheet is different from all the other sheets the design of it has been specially guided by the architects. What is required on the sheet along with what how to display it is gained from the architects.

Future work would involve displaying the calculation methods along with a breakdown of each formula used. This has not currently been done as other aspects of the calculator are prioritised.

\subsection{Design Advice}

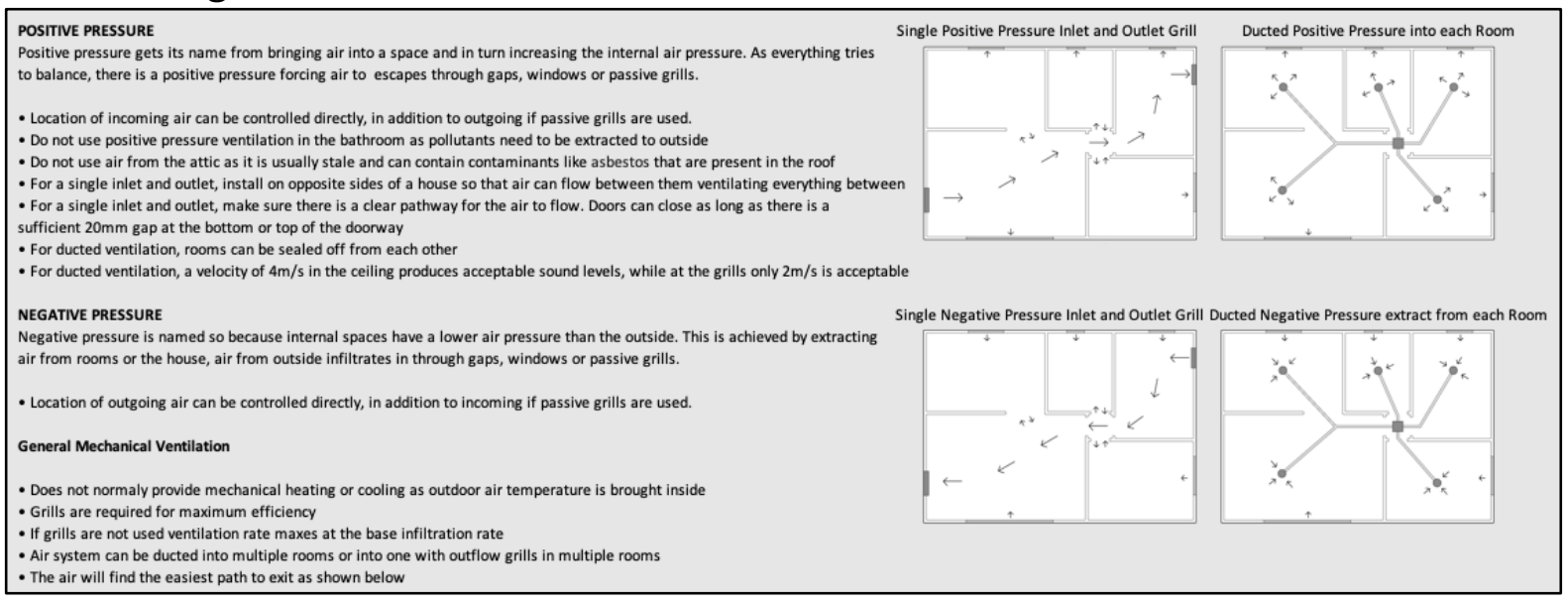

Figure 19: Design Advice Sheet 
Design advice was originally used when the ventilation sheet let the user select if they are using positive, negative, or balanced pressure ventilation. As there are benefits and down sides to each of these.

The sheet displays images of how air would flow for two different systems under different pressures, they are also shown in section 7.1 Unbalanced Pressures. Along with each image, are points to consider when selecting that ventilation technique, although the selection method has been replaced in the ventilation sheet, this sheet remains as it provides helpful information to the user.

Future work would involve providing specific advice to the user for each system that has been previously selected. Therefore, they know why each system is being used and can inform clients of the decisions.

\subsection{Heat Loss Results}

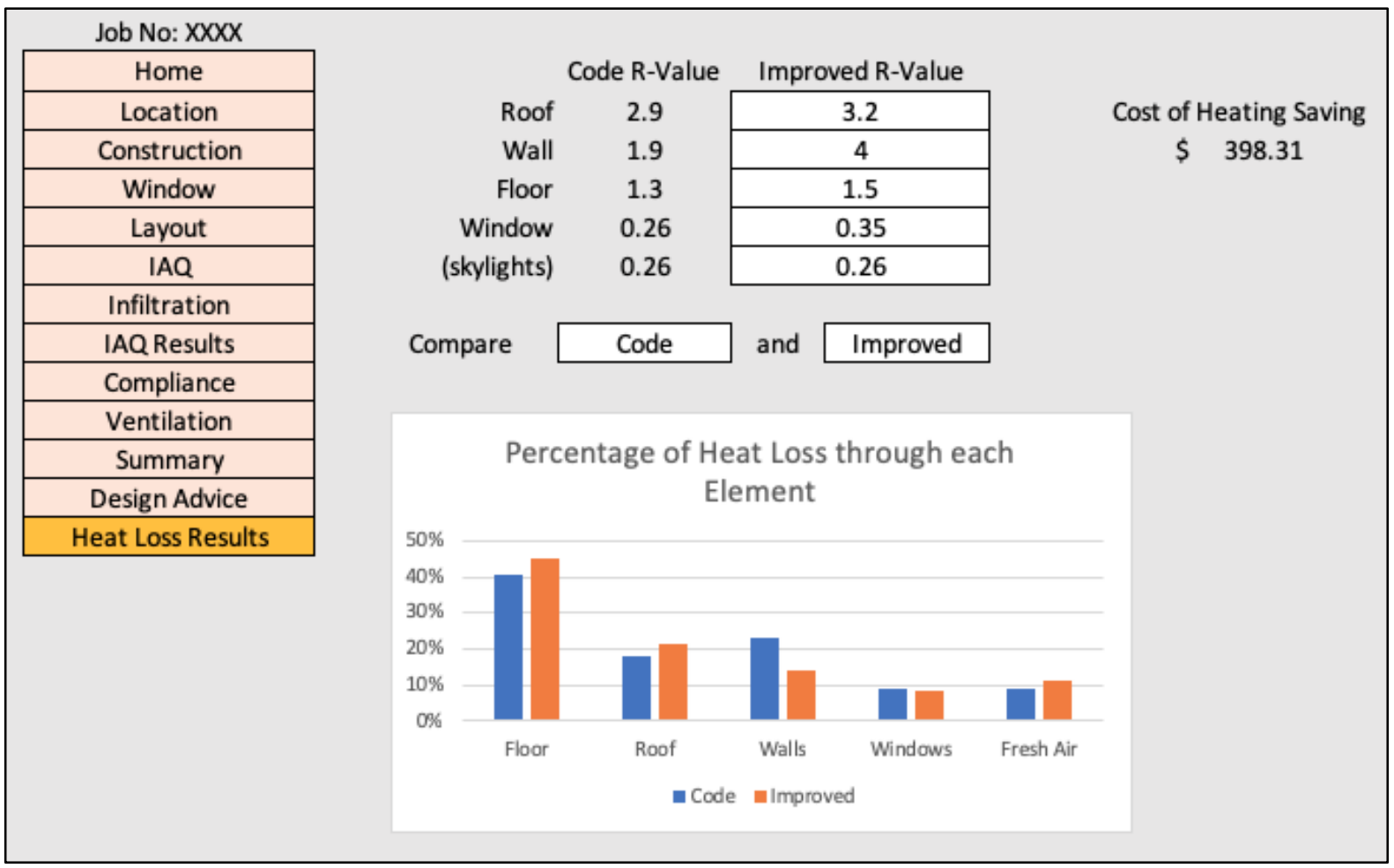

Figure 20: Heat Loss Results Sheet

Heat loss results can be used to compare the house with code level minimum insulation to an improved R-Value. The amount of heat loss through each element is shown along with the amount of money saved from reduced energy costs. The improved values are input next to the code requirements for that location which are automatically selected.

Heat loss is calculated using the formula below from NZS 4218 (Standards, 2009), where the area of a surface is divided by the R-Value. This is completed for each surface of the house to calculate what amount of heat is lost through each element. While, the amount of heat loss from fresh air ventilation is calculated through the volume of the space, heat capacity of air, and ventilation rate in air changes per hour. 


$$
H L=\frac{A}{R-\text { Value }}
$$

For future work on this sheet would be to let the user select what they want to compare. If they wanted to see the effects a heat recovery system would have on energy saving they would be able to compare the two.

A limitation is, only basic heat loss calculations are completed based off of locational degree day calculations. This is an average approximation of how the weather would be over a year.

\subsection{Maintenance}

\begin{tabular}{|c|c|c|c|c|c|c|c|}
\hline \multirow{3}{*}{$\begin{array}{l}\max \\
\min \end{array}$} & \multirow{3}{*}{$\begin{array}{l}29 \\
16\end{array}$} & \multirow{2}{*}{$\begin{array}{l}\text { System } \\
\text { Heat Recovery Wall Mounted }\end{array}$} & \multirow{2}{*}{$\begin{array}{l}\text { Brand } \\
\text { Mitsubishi }\end{array}$} & \multirow{2}{*}{$\begin{array}{l}\text { Number } \\
\text { VL-100EU5-E }\end{array}$} & \multirow{2}{*}{$\frac{\text { Min }}{16}$} & \multirow{2}{*}{\begin{tabular}{c|} 
Energy \\
15 \\
\end{tabular}} & \multirow{2}{*}{$\begin{array}{l}\text { Cost } \\
646\end{array}$} \\
\hline & & & & & & & \\
\hline & & Heat Recovery Wall Mounted & Mitsubishi & VL-100EU5-E & 29 & 31 & 646 \\
\hline \multirow{20}{*}{$\begin{array}{l}\max \\
\min \end{array}$} & 97 & Heat Recovery System & Mitsubishi & VL-220CZGV-E & 18 & 8.5 & 2497 \\
\hline & 5.5 & Heat Recovery System & Mitsubishi & VL-220CZGV-E & 33 & 18.5 & 2497 \\
\hline & & Heat Recovery System & Mitsubishi & VL-220CZGV-E & 46 & 35 & 2497 \\
\hline & & Heat Recovery System & Mitsubishi & VL-220CZGV-E & 64 & 80 & 2497 \\
\hline & & Heat Recovery System & Fantech & ComfoAir Q350 & 42 & 16 & 3028 \\
\hline & & Heat Recovery System & Fantech & ComfoAir Q350 & 55.5 & 31 & 3028 \\
\hline & & Heat Recovery System & Fantech & ComfoAir Q350 & 68 & 43 & 3028 \\
\hline & & Heat Recovery System & Fantech & ComfoAir Q350 & 69 & 59 & 3028 \\
\hline & & Heat Recovery System & Fantech & ComfoAir Q350 & 83 & 77 & 3028 \\
\hline & & Heat Recovery System & Fantech & ComfoAir Q350 & 97 & 98 & 3028 \\
\hline & & Heat Recovery System & Fantech & ComfoAir Q350 & 69 & 74 & 3028 \\
\hline & & Heat Recovery System & Fantech & ComfoAir Q350 & 69 & 88 & 3028 \\
\hline & & Heat Recovery System & Fantech & ComfoAir Q350 & 83 & 108 & 3028 \\
\hline & & Heat Recovery System & Fantech & ComfoAir Q350 & 97 & 131 & 3028 \\
\hline & & Heat Recovery System & Fantech & ComfoAir 200 & 6 & 9 & 2950 \\
\hline & & Heat Recovery System & Fantech & ComfoAir 200 & 16 & 14 & 2950 \\
\hline & & Heat Recovery System & Fantech & ComfoAir 200 & 25 & 20 & 2950 \\
\hline & & Heat Recovery System & Fantech & ComfoAir 200 & 33 & 30 & 2950 \\
\hline & & Heat Recovery System & Fantech & ComfoAir 200 & 43 & 46 & 2950 \\
\hline & & Heat Recovery System & ECO Heating & CWL-F-150 & 41 & 52 & $?$ \\
\hline
\end{tabular}

Figure 21: Maintenance Sheet

The maintenance sheet is used to provide a list of all the current systems being accessed in the calculator. It can be added to if new models are found or systems implemented.

By inserting a new row under the intended system the calculator picks up that the input is intended for that set of systems, and can then suggest it if required. The full list of systems can be seen in Appendix One. 
This sheet was initially suggested by the architects so that the calculator would not become redundant with age. Future work on this sheet would allow the users to maintain more aspect of the calculator and update values like the weather files or windows types. Having the calculator suggest a system based upon a user's preference for higher ventilation rate, lower energy consumption, or lower cost would help designers tend to their clients better.

\subsection{Ventilation Calculations}

\begin{tabular}{|c|c|c|c|c|c|c|c|c|c|c|}
\hline Wind speed & & $\begin{array}{c}\text { Temp } \\
\text { inside } \\
\end{array}$ & Temp outside & $\begin{array}{c}\text { Displacement } \\
\text { coefficient }\end{array}$ & $\begin{array}{l}\text { Coefficient Values } \\
\text { Incidence Angle }\end{array}$ & C1 & C2 & C3 & Angle of wind & Façade Exposure \\
\hline 1.994963601 & & 291 & 286 & 0.6 & Original Value & 0.001 & 0.0035 & 0.01 & 180 & Semi-Exposed \\
\hline Single Opening & Open area & $\begin{array}{l}\text { Height of } \\
\text { opening }\end{array}$ & BSM Wind only & BSM Temp Difference & $\begin{array}{c}\text { Warren and Parkins - } \\
1984\end{array}$ & Warren - 1977 & $\begin{array}{l}\text { Phaff and De } \\
\text { Gids - } 1982\end{array}$ & $\begin{array}{l}\text { Larsen and Heiselberg - } \\
2008\end{array}$ & & \\
\hline G Floor Bed 1 & 0.6 & 0.4 & 0.030 & 0.032 & 0.068 & 0.044 & 0.044 & 0.021 & & \\
\hline G Floor Bed 2 & 0.72 & 0.8 & 0.036 & 0.054 & 0.090 & 0.065 & 0.061 & 0.025 & & \\
\hline G Floor Bath 1 & 1.2 & 0.8 & 0.060 & 0.090 & 0.150 & 0.108 & 0.101 & 0.041 & & \\
\hline G Floor Liv 1 & 1.2 & 0.4 & 0.060 & 0.064 & 0.136 & 0.088 & 0.088 & 0.041 & & \\
\hline G Floor Kit 1 & 0.3 & 0.4 & 0.015 & 0.016 & 0.034 & 0.022 & 0.022 & 0.010 & & \\
\hline G Floor Hall 1 & 0 & 0 & 0.000 & 0.000 & 0.000 & 0.000 & 0.000 & 0.000 & & \\
\hline
\end{tabular}

Figure 22: Calculation Sheet

The ventilation calculation sheet generates the ventilation rate for a space using all of the formulas discussed in section 5.6 Single Sided Ventilation and section 10.0 Ventilation Formulae, using the same inputs. This lets the user select what formula is correct for them and what they are requiring.

Other than displaying all of the information about the different formulas and inputs this sheet is not intended to be seen by any users but advanced users that want to change the ventilation formula being used. Therefore, it is automatically hidden in the Excel Spread sheet and has to be manually unhidden to be used. Calculations on this page reference to all other pages in the workbook to source information that is input or calculated on them.

\subsection{Discussion}

With the standard, NZS 4303:1990, and the New Zealand Building Code section G4, there are only two ways to prove compliance. One of these methods, G4, does not directly account for the ventilation rates achievable, it only prescribes a value that must be reached, of $5 \%$ openable window area compared to floor area. This is the most common means of proving compliance, as it is a simple calculation for designers to perform. The down sides are, there is no accountability if occupants don't open their windows and, therefore won't be ventilating. In addition, the large amount of variant ventilation rates that can be achieved with different types of windows is not considered. Although, NZS 4303:1990 goes a step further in the correct direction and prescribes ventilation rates that must be achieved through natural or mechanical ventilation. Which means, window types and systems actually matter. However, there are still problems, as If a building has been calculated to work with natural ventilation and occupants don't open their windows, these rates won't be achieved. This is the reason for compiling data for a ventilation calculator.

The proposed process for calculating ventilation rates in Section 12, takes into account a lot more factors than the current method used in practice. These additional factors improve the accuracy of the calculation and are there for more accurately representing the ventilation rates that can be achieved. The ease of which a user can achieve these results is 
imperative as well, if the calculator is to complex or confusing to use, designers would just return to the method they know how to do. This is why a lot of work has gone into reducing information input fields and letting the calculator determine which option is the best.

The fact that this calculator has been incorporated into a common software like excel means its accessible to almost everyone. There are some limitations to excel that made applying some formulas not possible as well as making design choices more difficult to implement. The benefits for using a spread sheet comes from that most people are familiar with one, they understand where to put input and how outputs are calculated. Being able to provide graphical information alongside the inputs helped a lot in the usability factor. In the future, applying all the calculations and information gained in creating the spread sheet calculator towards a website or application, would allow more freedom to what can be achieved in terms of aesthetics as well as calculations.

Assumptions are made throughout the calculator. The largest being that the correct formula is being used, as shown in section 10, there is a large variance in results produced. An experts opinion suggests the formula that is currently set, by Phaff and De Gids, but the option to change is available. More research on what formula reflects reality best for design implications would be needed to know for sure. Another assumption is that rooms can be combined and that providing $80 \%$ clear wall area between spaces is sufficient. This is a problem as the formulas that have been used, assume that there are not barriers blocking air flow.

\subsection{Conclusion}

An architect can use the spreadsheet calculator to determine ventilation rates for each room in a house and a mechanical system that can be used to for fill that requirement, in addition to being shown which compliance paths are proven. This is a large implication as time can be saved through architects not having to do repetitive NZBC G4 calculations. Although this is the outcome of the research project, there is also information gained around the different processes used by architects to complete ventilation calculations. These are compared in the discussion section. With all the feedback gained from testing the calculator, vast improvements have been made on the processes in addition to design. Although in the future, more adaptions may become needed as the process is used more often in practice by inexperienced users. 


\section{References}

ADAMOVSKY, D. 2018. Building Ventilation Systems. Department of Microenvironmental and Building Services engineering.

AKBARI, K. \& OMAN, R. 2013. Impacts of Heat Recovery Ventilators on Energy Savings and Indoor Radon in a Swedish Detached House. WSEAS TRANSACTIONS on ENVIRONMENT and DEVELOPMENT, 9, 10.

ATKINSON J, CHARTIER Y \& CL, P.-S. 2009. Natural Ventilation for Infection Control in Health-Care Settings., World Health Organization.

BASSETT, M. 2001. Naturally Ventilated Houses In New Zealand - Simplified Air Infiltration Prediction. CIB World Building Congress. Wellington, New Zealand: BRANZ.

BISHOP, R. 1987. Ventilation to Reduce Indoor Condensation. Building Research Association of New Zealand: BRANZ.

BRANZ. 2017. Passive Ventilation Fixtures [Online]. Level. Available: http://www.level.org.nz/passivedesign/ventilation/passive-ventilation-fixtures/ [Accessed 21/11/18].

BRANZ. 2018. Ventilation [Online]. Web. Available: https://www.branz.co.nz/cms_display.php?sn=152\&pg=21236 [Accessed 8/2/2019].

CHOI, Y.-H., SONG, D., SEO, D. \& KIM, J. 2018. Analysis of the variable heat exchange efficiency of heat recovery ventilators and the associated heating energy demand. Energy and Buildings, 172.

CIBSE 1997. Natural ventilation in non-domestic buildings. AM10:1997. Great Britain: Bath Midway Press.

CIBSE 2008. CIBSE Concise Handbook. Third ed. The Chartered Institution of Building Services Engineers London.

COTTERELL, J. \& DADEBY, A. 2012. The Passivhaus Handbook, Green Books.

GIDS, W. D. \& PHAFF, H. 1982. Ventilation rates and energy consumption due to open windows: A brief overview of research in the Netherlands. Air infiltration review, 4, 1.

GINESTET, A., PUGNET, D. \& MOURADIAN, L. 2014. Performances, classification and impact on energy consumption of air filters for balanced ventilation systems with heat recovery for dwellings. Indoor Air Quality and Climate. Hong Kong.

JOKISALO, J., KURNITSKI, J., VUOLLE, M. \& TORKKI, A. 2016. Performance of Balanced Ventilation with Heat Recovery in Residential Buildings in a Cold Climate. International Journal of Ventilation.

LARSEN, T. S. \& HEISELBERG, P. 2008. single-sided natural ventilation driven by a combination of wind pressure and temperature difference. Department of Civil Engineering, Aalborg University, Denmark.

MBIE 2017. G4. Ventilation. Ministry of Business Innovation and Employment. 
PERSILY, A. \& JONGE, L. D. 2016. Carbon dioxide generation rates for building occupants. WILEY.

PRIYADARSINI, R., CHEONG, K. W. \& WONG, N. H. 2004. Enhancement of natural ventilation in high-rise residential buildings using stack system. Energy and Buildings, 36, 61-71.

QUAGLIA, L. \& MCNEIL, S. 2011. Changing The Air Indoors. BUILD, 2.

SANTAMOURIS, M. \& ASIMAKOPOULOS, D. 1997. Passive Cooling of Buildings, James \& James.

SHARPE, T., FARREN, P., HOWIESON, S., TUOHY, P. \& MCQUILLAN, J. 2015. Occupant Interactions and Effectiveness of Natural Ventilation Strategies in Contemporary New Housing in Scotland, UK. International Journal of Environmental Research and Public Health, 12.

STANDARDS, N. Z. 2009. NZS 4218:2009. Standards NZ.

WANG, H. \& CHEN, Q. 2012. A new empirical model for predicting single-sided, wind-driven natural ventilation in buildings. Energy and Buildings, 54, 8.

WARREN, P. Ventilation through openings on one wall only. Proceeding of international center for heat and mass transfer, seminar energy conservation in heating, cooling, and ventilating buildings., 1977. Hemisphere Publishing Corporation.

WARREN, P. \& PARKINS, L. 1984. Window-opening behaviour in office buildings. Building Serv. Eng. Res. Technol., 5.

WHITE, V. \& JONES, M. 2017. Warm, dry, healthy? Insights from the 2015 House Condition Survey on insulation, ventilation, heating and mould in New Zealand houses. BRANZ.

WHO 2018. Ambient air quality and health. World Health Organisation. 


\section{Priority Reading}

ATKINSON J, CHARTIER Y \& CL, P.-S. 2009. Natural Ventilation for Infection Control in HealthCare Settings., World Health Organization.

This report produced for the World Health Organization covers what sorts of natural ventilation are required and could be used for controlling infection in health care settings. Aside from its main recommendations to help prevent airborne infections and setting minimum hourly averaged ventilation rates for patients in airborne precaution rooms, the main use for this document is how it has set out definitions of mechanical and natural ventilation. The report also includes calculation methods for cross ventilation and buoyancy forces.

BASSETT, M. 2001. Naturally Ventilated Houses In New Zealand - Simplified Air Infiltration Prediction. CIB World Building Congress. Wellington, New Zealand: BRANZ.

This conference paper presents research which outlines the steps and quantifies values to calculate air infiltration predictions. Work by Bassett goes into understanding why the New Zealand Building Code and related Standards have never required residential buildings to meet airtightness targets. In addition to, discussion of the changing airtightness profile for New Zealand houses and proposals of a way to classify homes into four different airtightness categories. The simplified method for estimating average infiltration rates for these airtightness categories has been developed by modelled infiltration rates using the BREEZE program that has been created by BRE in the UK with New Zealand climate and building data. The simplified model draws on airtightness survey information and tracer studies to link average infiltration rates to the age and type of building. These are further refined with specific allowances for simple passive ventilators, a range of well-defined leakage openings, such as gaps under doors, and then further modified according to the geographic location of the building and local wind shielding.

PRIYADARSINI, R., CHEONG, K. W. \& WONG, N. H. 2004. Enhancement of natural ventilation in high-rise residential buildings using stack system. Energy and Buildings, 36, 61-71.

This paper describes the feasibility study on the application of passive and active stack systems to enhance natural ventilation in public housing in Singapore. About $86 \%$ of the population is staying in high-rise public housing, or flats, which are designed for natural ventilation. The primary objective of this work is to assess the status of natural ventilation in a typical four-room flat using scaled model in the wind tunnel, and to develop an effective passive or active stack system to enhance 
natural ventilation in the flat. Four numbers of stacks with different sizes were tested at two locations in the flat. The study shows that the passive stack, incorporating the principle of airflow due to buoyancy, does not enhance air velocity in the flat. However, the active stack which operates based on the suction effect induced by a fan fixed at the top of the stack leads to substantial increase in the air velocity at the room and therefore, meeting the human's thermal comfort condition.

WANG, H. \& CHEN, Q. 2012. A new empirical model for predicting single-sided, wind-driven natural ventilation in buildings. Energy and Buildings, 54, 8.

Prediction of single-sided natural ventilation is difficult due to the bi-directional flow at the opening and the complex flow around buildings. A new empirical model was developed that can predict the mean ventilation rate and fluctuating ventilation rate due to the pulsating flow and eddy penetration of single-sided, wind-driven natural ventilation in buildings. The governing equation is based on the non-uniform pressure distribution along the opening height. The new model shows that the ventilation rate and wind velocity are linearly correlated. This investigation studied the eddy penetration effect in the frequency domain based on fast Fourier transform. Large Eddy Simulation (LES) and experimental data were used to validate the new empirical model. The model has also been used to analyze the influence of the opening geometry and elevation on the ventilation rate

\section{Appendix One}

\begin{tabular}{|c|c|c|c|c|c|}
\hline System Type & Brand & Product Number & $\begin{array}{c}\text { Air Flow } \\
(1 / s)\end{array}$ & $\begin{array}{l}\text { Energy } \\
\text { (W) }\end{array}$ & $\begin{array}{c}\text { Cost } \\
(\$)\end{array}$ \\
\hline Heat Recovery Wall Mounted & Mitsubishi & VL-100EU5-E & 16 & 15 & 646 \\
\hline Heat Recovery Wall Mounted & Mitsubishi & VL-100EU5-E & 29 & 31 & 646 \\
\hline
\end{tabular}

\begin{tabular}{|l|c|c|c|c|c|}
\hline Heat Recovery System & Mitsubishi & VL-220CZGV-E & 18 & 8.5 & 2497 \\
\hline Heat Recovery System & Mitsubishi & VL-220CZGV-E & 33 & 18.5 & 2497 \\
\hline Heat Recovery System & Mitsubishi & VL-220CZGV-E & 46 & 35 & 2497 \\
\hline Heat Recovery System & Mitsubishi & VL-220CZGV-E & 64 & 80 & 2497 \\
\hline Heat Recovery System & Fantech & ComfoAir Q350 & 42 & 16 & 3028 \\
\hline Heat Recovery System & Fantech & ComfoAir Q350 & 55.5 & 31 & 3028 \\
\hline Heat Recovery System & Fantech & ComfoAir Q350 & 68 & 43 & 3028 \\
\hline Heat Recovery System & Fantech & ComfoAir Q350 & 69 & 59 & 3028 \\
\hline Heat Recovery System & Fantech & ComfoAir Q350 & 83 & 77 & 3028 \\
\hline Heat Recovery System & Fantech & ComfoAir Q350 & 97 & 98 & 3028 \\
\hline Heat Recovery System & Fantech & ComfoAir Q350 & 69 & 74 & 3028 \\
\hline Heat Recovery System & Fantech & ComfoAir Q350 & 69 & 88 & 3028 \\
\hline Heat Recovery System & Fantech & ComfoAir Q350 & 83 & 108 & 3028 \\
\hline
\end{tabular}




\begin{tabular}{|c|c|c|c|c|c|}
\hline Heat Recovery System & Fantech & ComfoAir Q350 & 97 & 131 & 3028 \\
\hline Heat Recovery System & Fantech & ComfoAir 200 & 6 & 9 & 2950 \\
\hline Heat Recovery System & Fantech & ComfoAir 200 & 16 & 14 & 2950 \\
\hline Heat Recovery System & Fantech & ComfoAir 200 & 25 & 20 & 2950 \\
\hline Heat Recovery System & Fantech & ComfoAir 200 & 33 & 30 & 2950 \\
\hline Heat Recovery System & Fantech & ComfoAir 200 & 43 & 46 & 2950 \\
\hline Heat Recovery System & ECO Heating & CWL-F-150 & 41 & 52 & $?$ \\
\hline
\end{tabular}

\begin{tabular}{|c|c|c|c|c|c|}
\hline Heat Recovery Decentralised & Fantech & AEROHR-150/PRO & 6 & 2.4 & $?$ \\
\hline Heat Recovery Decentralised & Fantech & AEROHR-150/PRO & 11 & 4.1 & $?$ \\
\hline Heat Recovery Decentralised & Fantech & AEROHR-150/PRO & 17 & 6.9 & $?$ \\
\hline Heat Recovery Decentralised & Zehnder & ComfoSpot 50 & 4 & 5 & 1300 \\
\hline Heat Recovery Decentralised & Zehnder & ComfoSpot 50 & 15 & 15 & 1300 \\
\hline Heat Recovery Decentralised & Zehnder & ComfoAir 70 & 4 & 4 & 1824 \\
\hline Heat Recovery Decentralised & Zehnder & ComfoAir 70 & 17 & 17 & 1824 \\
\hline Heat Recovery Decentralised & ECO Heating & CWL-D-70 & 19 & 20 & $?$ \\
\hline
\end{tabular}

\begin{tabular}{|l|l|l|l|l|c|}
\hline Through Wall Extractor Fan & Manrose & XF150S & 87 & 25 & 131 \\
\hline Through Wall Extractor Fan & Manrose & XF125S & 36 & 20 & 89 \\
\hline Through Wall Extractor Fan & Manrose & XF100S & 23 & 20 & 68 \\
\hline
\end{tabular}

\begin{tabular}{|l|l|l|l|l|l|}
\hline Ducted Extractor Fan & Manrose & MKLP150S & 156 & 60 & $?$ \\
\hline Ducted Extractor Fan & Manrose & SFLP150S & 94 & 60 & $?$ \\
\hline Ducted Extractor Fan & Manrose & MKLP125S & 89 & 40 & $?$ \\
\hline Ducted Extractor Fan & Manrose & SFLP125S & 39 & 40 & $?$ \\
\hline Ducted Extractor Fan & Manrose & MKLP100S & 69 & 40 & $?$ \\
\hline
\end{tabular}

\begin{tabular}{|c|c|c|c|c|c|}
\hline Air Handling Unit & Holyoak & $100 \mathrm{~mm}$ & 20 & $?$ & $?$ \\
\hline Air Handling Unit & Holyoak & $100 \mathrm{~mm}$ & 105 & $?$ & $?$ \\
\hline Air Handling Unit & Holyoak & $125 \mathrm{~mm}$ & 35 & $?$ & $?$ \\
\hline Air Handling Unit & Holyoak & $125 \mathrm{~mm}$ & 166 & $?$ & $?$ \\
\hline Air Handling Unit & Holyoak & $150 \mathrm{~mm}$ & 67 & $?$ & $?$ \\
\hline Air Handling Unit & Holyoak & $150 \mathrm{~mm}$ & 239 & $?$ & $?$ \\
\hline
\end{tabular}

